\title{
Examination of the Global Regulon of CsrA in Xanthomonas citri subsp. citri Using Quantitative Proteomics and Other Approaches
}

\author{
Yanan Zhang, ${ }^{1,2}$ Maxuel O. Andrade, ${ }^{1,3}$ Wenting Wang, ${ }^{1,4}$ Doron Teper, ${ }^{1}$ Tony Romeo, ${ }^{5}$ and Nian Wang ${ }^{1, \dagger}$ \\ ${ }^{1}$ Citrus Research and Education Center, Department of Microbiology and Cell Sciences, University of Florida, 700 \\ Experiment Station Road, Lake Alfred FL 33850, U.S.A. \\ ${ }^{2}$ Center for Yunnan Plateau Biological Resources Protection and Utilization, College of Biological Resource and Food \\ Engineering, Qujing Normal University, Qujing, Yunnan, 655011, China \\ ${ }^{3}$ Brazilian Biorenewables National Laboratory (LNBR), Brazilian Centre for Research in Energy and Materials (CNPEM), \\ Campinas, SP, Brazil \\ ${ }^{4}$ Department of Plant Pathology, University of Florida, Gainesville FL 32611, U.S.A. \\ ${ }^{5}$ Department of Microbiology and Cell Sciences, University of Florida, Gainesville FL 32611, U.S.A.
}

Accepted 17 July 2021.

The RNA-binding protein CsrA is a global posttranscriptional regulator and controls many physiological processes and virulence traits. Deletion of $\operatorname{csr} A$ caused loss of virulence, reduced motility and production of xanthan gum and substantial increase in glycogen accumulation, as well as enhanced bacterial aggregation and cell adhesion in Xanthomonas spp. How CsrA controls these traits is poorly understood. In this study, an isobaric tag for relative and absolute quantitation (iTRAQ)-based proteomic analysis was conducted to compare the protein profile of wild-type strain Xanthomonas citri subsp. citri and the isogenic $\Delta c s r A$ strain. A total of 2,374 proteins were identified, and 284 were considered to be differentially expressed proteins $\left(\right.$ DEP $\left._{S}\right)$, among which 151 proteins were up-regulated and 133 were downregulated in the $\Delta c s r A$ strain with respect to the wild-type strain. Enrichment analysis and a protein-protein interaction network analysis showed that CsrA regulates bacterial secretion systems, flagella, and xanthan gum biosynthesis. Several proteins encoded by the gumB operon were down-regulated, whereas proteins associated with flagellum assembly and the type IV secretion system were up-regulated in the $\Delta c s r A$ strain relative to the $\mathrm{Xcc} 306$ strain. These results were confirmed by $\beta$-glucuronidase assay or Western blot. RNA secondary structure prediction and a gel-shift assay indicated that CsrA binds to the Shine-Dalgarno sequence of virB5. In addition, the iTRAQ analysis identified 248 DEPs that were not previously identified in transcriptome analyses. Among them, CsrA regulates levels of eight regulatory proteins

${ }^{\dagger}$ Corresponding author: N. Wang; nianwang@ufl.edu

Funding: This study has been supported by USDA-NIFA Plant Biotic Interactions Program 2017-67013-26527, Florida Citrus Initiative, and Florida Citrus Research and Development Foundation.

*The $e$-Xtra logo stands for "electronic extra" and indicates there are supplementary materials published online.

The author(s) declare no conflict of interest.

(c) (1) () $\odot$ Copyright $\odot 2021$ The Author(s). This is an open access article (c)
(ColR, GacA, GlpR, KdgR, MoxR, PilH, RecX, and YgiX), seven TonB-dependent receptors, four outer membrane proteins, and two ferric enterobactin receptors. Taken together, this study greatly expands understanding of the regulatory network of CsrA in X. citri subsp. citri.

Keywords: citrus, CsrA, iTRAQ, posttranscriptional regulation, T4SS, virB5, Xanthomonas citri subsp. citri

Posttranscriptional regulation plays an important role in coordinating various traits, which helps bacteria rapidly respond to the changing environment (Babitzke et al. 2019). Csr (carbon storage regulator) or Rsm (repressor of stationary-phase metabolites) systems are involved in posttranscriptional regulation in Gammaproteobacteria and others (Romeo et al. 2013). CsrA/ RsmA (hereafter CsrA) is a global posttranscriptional regulator and controls many physiological processes and virulenceassociated traits, including central carbon metabolism, stress response, secretion system biogenesis, cell motility, biofilm formation, quorum sensing, production of extracellular products, amylase, and siderophore production (Vakulskas et al. 2015; Tang et al. 2021).

The regulatory mechanisms of CsrA have been welldocumented in the model microorganism Escherichia coli (Pourciau et al. 2020). Its binding to RNA may cause changes in, singly or in combination, RNA secondary structure, RNA stability, translation, or Rho-mediated transcription termination (Romeo and Babitzke 2018). CsrA-mediated translational repression typically involves CsrA binding to either the $5^{\prime}$ untranslated region ( $5^{\prime}$ UTR), the initially translated region of target transcripts, or both. Overlap between a CsrA-binding site and the ribosome binding site (RBS) sequence blocks 30S ribosome access to the messenger RNA (mRNA) and inhibits translation (Babitzke and Romeo 2007). The canonical CsrA binding site often consists of a conserved GGA-containing sequence located in a hairpin loop, although CsrA also recognizes unstructured RNA (Dubey et al. 2005; Duss et al. 2014). In the last five years, a series of transcriptomic studies, including the application of crosslinking and immunoprecipitation followed by sequencing, have revealed that CsrA-binding transcripts vary substantially in different bacterial species (Dugar et al. 2016; 
Holmqvist et al. 2016; Potts et al. 2017; Sahr et al. 2017; Sowa et al. 2017).

The activity of CsrA is regulated in various modes. Small RNAs (sRNAs) that bind tightly to CsrA and antagonize its activity are a common feature of $\mathrm{Csr} / \mathrm{Rsm}$ systems. Multiple sRNAs have been identified in Gammaproteobacterial species, such as CsrB and CsrC from E. coli (Weilbacher et al. 2003) and RsmY and RsmZ from Pseudomonas aeruginosa (Kay et al. 2006). Transcription of these regulatory sRNA, in return, is controlled by two-component systems, such as BarA-UvrY or GacS-GacA (Vakulskas et al. 2015), stringent response regulators (p)ppGpp and DksA (Edwards et al. 2011), and other regulators. Turnover of these RNAs in some species is regulated by the protein CsrD, which responds to preferred carbon sources (Leng et al. 2016; Suzuki et al. 2006; Vakulskas et al. 2016). In addition to regulatory sRNAs, protein antagonists of CsrA were also identified in some species, such as FliW in Bacillus subtilis (Mukherjee et al. 2011) and CesT in enteropathogenic E. coli (Katsowich et al. 2017). Expression of $\operatorname{csr} A$ itself is also regulated (Yakhnin et al. 2011). Complex regulatory circuitry of the Csr system enables bacteria to exert precise and rapid control of CsrA levels and activity.

Significant progress has been made in elucidating the regulatory roles of Csr/Rsm systems in host-pathogen interactions, including regulating bacterial colonization factors and secretion systems (Kusmierek and Dersch 2018; Schulmeyer and Yahr 2017). However, the direct virulence-relevant targets of CsrA vary in different bacterial pathogens (Vakulskas et al. 2015). CsrA plays important roles in regulating virulence traits of Xanthomonas spp., which are important plant-pathogenic bacteria that cause diseases in hundreds of crops, including citrus canker caused by Xanthomonas citri subsp. citri (An et al. 2020; Ference et al. 2018). Citrus canker is a devastating disease that infects most commercial citrus varieties (Favaro et al. 2020; Ference et al. 2020). The most important virulence factors of $X$. citri subsp. citri are the type III secretion system (T3SS) and effectors secreted by the T3SS, such as PthA4 (Yan and Wang 2012). PthA4 is a transcription activator-like effector that activates the citrus canker susceptibility gene $L O B 1$ to cause the hypertrophy and hyperplasia symptoms (Duan et al. 2018; Hu et al. 2014; Jia and Wang 2020; Jia et al. 2017; Zhang et al. 2017). In addition, many other virulence-associated traits, such as quorum sensing ( $\mathrm{Li}$ et al. 2019), extracellular polysaccharides (EPS, e.g., xanthan gum) (Rigano et al. 2007), lipopolysaccharide (LPS) (Li and Wang, 2012; Yan et al. 2012), biofilm (Li and Wang 2011), and periplasmic proteins (Zhou et al. 2015), also contribute to $X$. citri subsp. citri infection and colonization as well as the development of canker symptoms. These virulence traits are regulated in response to cues from the host and environment via complex regulatory networks that include factors such as HrpG/HrpX, CsrA, YtrA, Lon, TfmR, and DksA (Andrade et al. 2014; Guo et al. 2011; Teper et al. 2019; Zhang et al. 2019a; Zhou et al. 2017, 2018). In the genus Xanthomonas, the csrA deletion mutant showed nearly complete loss of virulence, reduced motility and production of EPS, substantial increase in glycogen accumulation, as well as an enhanced bacterial aggregation and cell adhesion (Chao et al. 2008; Zhu et al. 2011). Biofilm formation and dispersal was modulated by CsrA in an indirect manner correlated with cyclic di-GMP and the Clp transcription factor ( $\mathrm{Lu}$ et al. 2012). CsrA activates the T3SS by stabilizing the 5' UTR of $h r p G$, the master virulence regulator (Andrade et al. 2014; Guo et al. 2011). Recently, CsrA of $X$. citri subsp. citri was found to control the type IV secretion system (T4SS) homeostasis by inhibiting the translation initiation of virB7 (Cenens et al. 2020).

The regulatory circuitry of the Csr/Rsm system in Xanthomonas remains poorly understood. First, CsrA-binding sRNAs similar to $\mathrm{CsrB} / \mathrm{C}$ have not yet been identified. Intriguingly, a genome-wide screening in $X$. campestris pv. campestris revealed a novel RNA that sequesters CsrA, which does not belong to the $\mathrm{CsrB} / \mathrm{C}$ family (Tang et al. 2020). Second, environmental cues and upstream regulators of $\operatorname{csr} A$ expression have yet to be identified. Finally, the direct targets of CsrA in Xanthomonas spp. remain largely unknown. We hypothesized that CsrA regulates direct targets beyond $h r p G$ and virB7 in Xanthomonas spp. Here, an isobaric tag for relative and absolute quantitation (iTRAQ)-based proteomic study was used to identify the proteins that are regulated by CsrA in X. citri subsp. citri. Proteomic study has been widely used in the study of different pathosystems (Cui et al. 2020; Wang et al. 2021; Yan et al. 2021). The putative targets were further verified and their roles were assessed using a variety of approaches. The results of this study greatly expand understanding of the regulatory network of CsrA in the genus Xanthomonas.

\section{RESULTS}

Proteome profiling of Xcc306 and isogenic $\Delta c s r A$ strains.

To investigate the global roles of CsrA in X. citri subsp. citri, iTRAQ was applied to generate protein profiles of the wild-type strain Xcc306 and its isogenic $\Delta$ csrA mutant cultured in hrpinducing medium XVM2. A total of 2,374 proteins were identified by iTRAQ (Supplementary Table S1), which account for about $53.6 \%$ of all protein-coding genes of Xcc306. Proteins with a ratio $(\Delta c s r A / W T)<0.77$ or $>1.3$ and a $P$ value $<0.05$ were considered as differentially expressed proteins (DEPs); 284 proteins were differentially expressed, including 151 upregulated and 133 downregulated proteins (Supplementary Table S2).

Comparison and enrichment analyses were performed using the iTRAQ data as well as transcriptomic data obtained previously by our lab (Andrade et al. 2014). A Venn diagram showed that expression effects of CsrA on 36 genes overlapped between the transcription and protein levels (Fig. 1A; Table 1). Further analysis classified the 36 genes into several functional categories, including chemotaxis and flagellum biosynthesis, T3SS and effector genes, T4SS, enzymes, and others (Table 1). Although the comparison of proteomic data and transcriptomic data displayed considerable differences with respect to CsrA regulation, enrichment analysis based on the COG (Clusters of Orthologous Groups of proteins) database showed that cell motility and intracellular trafficking and secretion are over-represented categories for both proteomic and microarray data (Table 2). The group of signal transduction mechanisms was enriched only for microarray data (Table 2), which may be associated with technical challenges in extraction and solubilization of membrane-associated signaling proteins (Walls and Loughran 2011). In addition, similar results were obtained from Kyoto Encyclopedia of Genes and Genomes (KEGG) pathway enrichment analysis using clusterProfiler (v3.16.1) (Yu et al. 2012). Based on iTRAQ data, pathways involved in flagellum assembly and bacterial secretion system were especially over-represented (Fig. 1B).

\section{Protein-protein interaction (PPI) analysis of the CsrA regulon.}

To reveal the regulon of CsrA and the putative proteinprotein association network, the protein-protein association data of Xcc306 was derived from the STRING database (Marees et al. 2018). The interaction data for all of the DEPs with an interaction score $\geq 0.50$ were extracted (Supplementary Table S3). The protein-protein association network was generated using software Cytoscape (v3.8.0) (Shannon et al. 2003). Three separate gene clusters were shown in circular layout and the closely correlated genes appeared to demonstrate similar trends at the protein level (Fig. 2). Apparently, most T4SS structural 

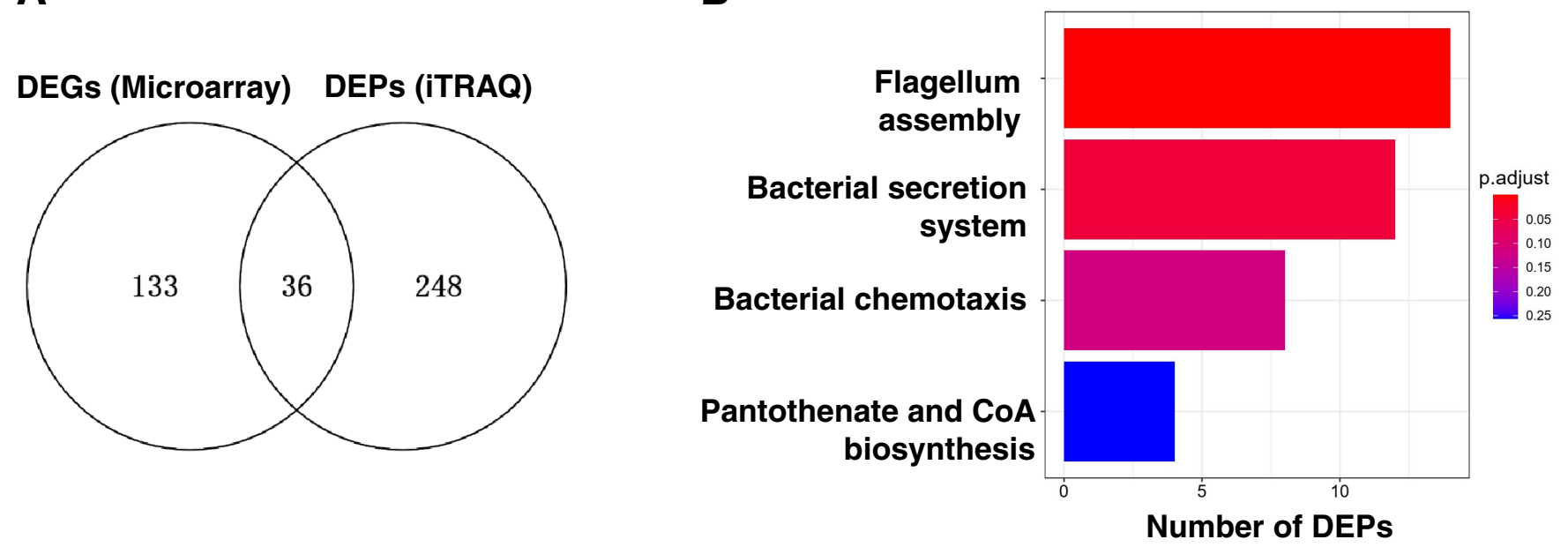

Fig. 1. Profiling the proteomes of Xcc306 and $\Delta c s r A$. A, Venn diagram of differentially expressed genes identified by isobaric tags for relative and absolute quantitation (iTRAQ) and microarray. B, Kyoto Encyclopedia of Genes and Genomes pathway enrichment analysis of differentially expressed proteins derived from iTRAQ data. The enrichment analysis was performed using R package clusterProfiler (v3.16.1). p.adjust represents adjusted $P$ value for multiple comparisons calculated by the Benjamini and Hochberg method (Benjamini and Hochberg 1995).

Table 1. Differentially expressed genes identified by both isobaric tags for relative and absolute quantitation (iTRAQ) and microarray analyses

\begin{tabular}{|c|c|c|c|c|}
\hline \multirow[b]{2}{*}{ Functional categories, locus tag } & \multirow[b]{2}{*}{ Gene } & \multirow[b]{2}{*}{ Protein product } & \multicolumn{2}{|c|}{ Fold change $^{a}$} \\
\hline & & & $\Delta \operatorname{csr} \mathbf{A} / \mathrm{WT}$ & $\Delta \operatorname{csr} A / W T$ \\
\hline \multicolumn{5}{|l|}{ Chemotaxis and flagellar biosynthesis } \\
\hline XAC1930 & cheA & Chemotaxis protein & 2.36 & 2.68 \\
\hline XAC1931 & cheZ & Chemotaxis protein & 2.86 & 4.76 \\
\hline XAC1933 & fliA & RNA polymerase sigma factor & 2.66 & 5.03 \\
\hline XAC1934 & fleN & Flagellar biosynthesis switch protein & 2.16 & 6.59 \\
\hline XАC1946 & fliN & Flagellar protein & 2.74 & 4.89 \\
\hline XAC1947 & fliM & Flagellar motor switch protein FliM & 2.38 & 4.06 \\
\hline XAC1948 & fliL & Flagellar protein & 2.39 & 3.56 \\
\hline XAC1949 & $f l i K$ & Flagellar protein & 1.60 & 3.27 \\
\hline XAC1954 & fliF & Flagellar MS-ring protein & 2.50 & 2.95 \\
\hline XAC1975 & $\mathrm{fliC}$ & Flagellin & 3.16 & 2.85 \\
\hline XАC1976 & flgL & Flagellar protein & 1.94 & 2.79 \\
\hline XAC1983 & $f \lg E$ & Flagellar hook protein FlgE & 4.02 & 2.97 \\
\hline XAC1932 & cheY & Chemotaxis protein & 2.87 & 5.43 \\
\hline \multicolumn{5}{|l|}{ Type III secretion system } \\
\hline XAC0076 & avrBS2 & T3S effector & 0.73 & 0.50 \\
\hline XAC1172 & хорАV & T3S effector & 0.68 & 0.40 \\
\hline \multicolumn{5}{|l|}{ Type IV secretion system } \\
\hline XAC2614 & $\operatorname{virB4}$ & VirB4 protein & 3.23 & 2.87 \\
\hline XAC2618 & virB11 & VirB11 protein & 3.82 & 5.24 \\
\hline XAC2619 & virB10 & VirB10 protein & 3.98 & 3.94 \\
\hline \multicolumn{5}{|l|}{ Enzyme } \\
\hline XАC0346 & - & Degenerated cellulase & 2.10 & 4.32 \\
\hline XAC0466 & - & Lytic enzyme & 3.53 & 3.12 \\
\hline XAC1200 & - & Prolyl oligopeptidase & 2.20 & 2.07 \\
\hline XАC3031 & - & Histidine kinase & 2.15 & 2.89 \\
\hline XAC2885 & - & Phospholipase A1 & 2.61 & 3.63 \\
\hline XАC2609 & - & Carboxypeptidase & 5.00 & 7.01 \\
\hline \multicolumn{5}{|l|}{ Hypothetical protein } \\
\hline XAC0467 & - & Hypothetical protein & 3.23 & 2.17 \\
\hline XAC1145 & - & Hypothetical protein & 2.70 & 2.17 \\
\hline XАC3267 & - & Hypothetical protein & 2.30 & 2.17 \\
\hline ХAC3279 & - & Hypothetical protein & 4.92 & 5.24 \\
\hline XAC3634 & - & Hypothetical protein & 5.34 & 3.05 \\
\hline XAC1397 & - & Hypothetical protein & 2.88 & 2.91 \\
\hline XAC2610 & - & Hypothetical protein & 5.31 & 4.69 \\
\hline XAC2443 & - & Hypothetical protein & 1.52 & 2.69 \\
\hline \multicolumn{5}{|l|}{ Others } \\
\hline ХAC0868 & - & Uncharacterized protein & 3.24 & 3.63 \\
\hline XAC2529 & $r h s D$ & RhsD protein & 2.00 & 3.29 \\
\hline XAC1907 & parA & Chromosome partioning protein & 1.89 & 4.59 \\
\hline XAC1573 & phoU & Phosphate regulon transcriptional regulator & 1.86 & 6.28 \\
\hline
\end{tabular}

${ }^{a}$ iTRAQ data and microarray data, respectively. 
proteins were up-regulated in the $\Delta c s r A$ strain compared with the Xcc306 strain (Fig. 2A). Also, many flagellum assembly proteins and some pilus assembly proteins were up-regulated in the $\Delta \operatorname{csr} A$ strain (Fig. 2B). However, several proteins involved in xanthan gum biosynthesis were down-regulated in the $\Delta c s r A$ strain compared with that of Xcc306 (Fig. 2C). Taken together, the biological network displays of the CsrA regulon in X. citri subsp. citri suggested a pivotal role of CsrA in T4SS, flagellum assembly, and xanthan gum biosynthesis.

\section{CsrA positively regulates the gum gene cluster.}

Xanthan gum is an EPS that contributes to biofilm formation, epiphytic fitness, and tolerance to environmental stress in Xanthomonas spp. (An et al. 2020; Büttner and Bonas 2010). Xanthan gum biosynthesis is mediated by the gum operon, which is composed of 12 enzyme-coding genes (gumB to gumM) (Vojnov et al. 2001). Although microarray data did not show that CsrA affects the expression of a gum gene cluster at the transcription level (Andrade et al. 2014), our proteomic analysis displayed that nine of 12 gum biosynthesis genes were down-regulated in the $\Delta c s r A$ strain compared with those of the wild-type strain Xcc306 (Fig. 3A). To further confirm this result, a reporter assay was applied to test the expression of $\operatorname{gumB}$, the first gene of this operon. $\beta$-Glucuronidase (GUS) assays using translational fusion plasmids showed that expression of gumB in the $\Delta \operatorname{csr} A$ strain was substantially lower than in the wild-type strain Xcc306 (Fig. 3B). Because a translational fusion measures both transcriptional and translation effects and our microarray data showed no effect, we inferred that CsrA positively regulates gumB and, most likely, other gum genes at the translational level.

CsrA negatively regulates flagellum assembly genes.

In the Xanthomonas genus, over 40 genes are involved in flagellum biogenesis and chemotaxis. Furthermore, expression of flagellum structural genes is regulated by several regulators in a hierarchical manner, including transcriptional regulator FleQ and RNA polymerase sigma factor FliA (Yang et al. 2009).
Genomic organization of $X$. citri subsp. citri flagellum genes spans from gene cheA (XAC1930) to gene flgM (XAC1989), many of which were regulated by CsrA at the protein or mRNA level (Fig. 4A). Furthermore, according to KEGG pathway analysis, 37 genes are associated with flagellum assembly in Xcc306, and expression data for these flagellum genes are listed in Supplementary Table S4. Among them, 14 and 20 of these genes were upregulated in $\triangle c s r A$ at protein and mRNA levels, respectively (Fig. 4B). Altogether, nine of 37 flagellum assembly genes exhibited similar regulatory effects at both the transcriptional and translational levels (Fig. 4B). To further confirm the expression changes from iTRAQ data, a hemagglutinin (HA) tag was inserted in-frame at the end of $f l e Q$ - and fliA-coding sequences of Xcc306 and the $\triangle c s r A$ strain. As expected, Western blot using anti-HA showed that FliA expression rather than FleQ expression is induced in $\Delta c s r A$ relative to Xcc306 (Fig. 4C). To summarize, these data indicate that CsrA of $X$. citri subsp. citri negatively regulates expression of the flagellar proteins.

\section{CsrA negatively regulates T4SS and its effectors.}

T4SS in X. citri subsp. citri is composed of a set of 12 core proteins, i.e., VirB1 through B11 plus VirD4, enabling X. citri subsp. citri to kill other competitive bacterial species by the secretion of T4SS effectors (toxins) (Souza et al. 2015). Our proteomic data show that most T4SS structural proteins as well as its effector protein (X-Tfe) were upregulated in $\Delta c s r A$ compared with that of wild-type strain Xcc306 (Fig. 5A). To further confirm this, a GUS assay was performed using a translational fusion construct. Consistent with proteomic data, GUS activity of virD4 in $\Delta c s r A$ strain was much higher than that of wild-type strain Xcc306 (Fig. 5B). In addition, some putative type IV effectors (XAC3634, XAC2609, XAC0466, XAC0096, XAC2885, XAC1918, $\mathrm{XAC} 3266)$ as well as their putative proximal immunity proteins (XAC3633, XAC2610, XAC0467, XAC0097, XAC2884) were up-regulated at the protein level or at the mRNA level in the $\Delta \operatorname{csr} A$ strain compared with the wild-type strain (Supplementary Table S5).

Table 2. Functional enrichment analysis based on Clusters of Orthologous Groups database

\begin{tabular}{|c|c|c|c|}
\hline \multirow[b]{2}{*}{ Functional classification } & \multirow[b]{2}{*}{ Abbreviation } & \multicolumn{2}{|c|}{$P$ value } \\
\hline & & Microarray & iTRAQ $^{b}$ \\
\hline RNA processing and modification & A & 1.00 & 1.00 \\
\hline Chromatin structure and dynamics & $\mathrm{B}$ & 1.00 & 1.00 \\
\hline Energy production and conversion & $\mathrm{C}$ & 0.02 & 0.89 \\
\hline Cell cycle control, mitosis and meiosis & $\mathrm{D}$ & 0.71 & 0.77 \\
\hline Amino acid transport and metabolism & $\mathrm{E}$ & 0.43 & 0.27 \\
\hline Nucleotide transport and metabolism & $\mathrm{F}$ & 0.26 & 0.28 \\
\hline Carbohydrate transport and metabolism & G & 0.40 & 0.52 \\
\hline Coenzyme transport and metabolism & $\mathrm{H}$ & 0.18 & 0.38 \\
\hline Lipid transport and metabolism & I & 0.07 & 0.43 \\
\hline Translation, ribosomal structure and biogenesis & $\mathrm{J}$ & 0.01 & 0.10 \\
\hline Transcription & $\mathrm{K}$ & 0.75 & 0.61 \\
\hline Replication, recombination, and repair & $\mathrm{L}$ & 0.01 & 0.02 \\
\hline Cell wall/membrane biogenesis & M & 1.00 & 0.18 \\
\hline Cell motility & $\mathrm{N}$ & 8.46E-18 & 3.86E-06 \\
\hline Posttranslational modification, protein turnover, chaperones & $\mathrm{O}$ & 0.83 & 0.62 \\
\hline Inorganic ion transport and metabolism & $\mathrm{P}$ & 0.31 & 1.00 \\
\hline Secondary metabolites biosynthesis, transport and catabolism & Q & 1.00 & 1.00 \\
\hline Function unknown & $\mathrm{S}$ & 0.54 & 0.69 \\
\hline Signal transduction mechanisms & $\mathrm{T}$ & 0.03 & 0.79 \\
\hline Intracellular trafficking and secretion & $\mathrm{U}$ & 1.18E-06 & $6.68 \mathrm{E}-03$ \\
\hline Defense mechanisms & $\mathrm{V}$ & 0.52 & 0.44 \\
\hline Extracellular structures & $\mathrm{W}$ & 1.00 & 1.00 \\
\hline Cytoskeleton & $\mathrm{Z}$ & 1.00 & 1.00 \\
\hline
\end{tabular}

${ }^{\mathrm{a}}$ iTRAQ $=$ isobaric tags for relative and absolute quantitation data. $P$ values were calculated by Fisher exact test. Bold indicates an over-represented group $(P$ value $<0.05)$. 
Interestingly, four T4SS-associated proteins $\left(\mathrm{X}-\mathrm{Tf} \mathrm{X}^{\mathrm{XAC2609}}\right.$, X-Tfi ${ }^{\text {XAC2610, }}$, VirB5 ${ }^{\text {XAC2613 }}$, VirB9 ${ }^{\text {XAC2620 }}$ ) belong to the top 10 upregulated proteins in the $\triangle c s r A$ strain compared with those of the wild-type strain Xcc306 (Fig. 5C). Based on the features of the CsrA-binding motif (Duss et al. 2014), DNA sequence analyses to search for potential CsrA-binding motifs were conducted for all genes in the VirB operon. Secondary mRNA structure analyses by Mfold (Zuker 2003) revealed one potential CsrA-binding target close to the translation start site of virB5.
The region of virB5 is predicated to form a hairpin structure with a hexa-loop composed of the conserved motif ANGGAX, suggesting that virB5 may be a putative CsrA-binding target (Fig. 5D). To further explore this, an electrophoretic mobilityshift assay (EMSA) was conducted, which showed that CsrA binds to the region of virB5 (Fig. 5E and F). Mutation of the predicted CsrA-binding site GGA (Fig. 5D) to TTA abolished the mobility shift caused by CsrA (Fig. 5F). As suspected, the CsrA-binding site overlaps with the Shine-Dalgarno sequence of
A

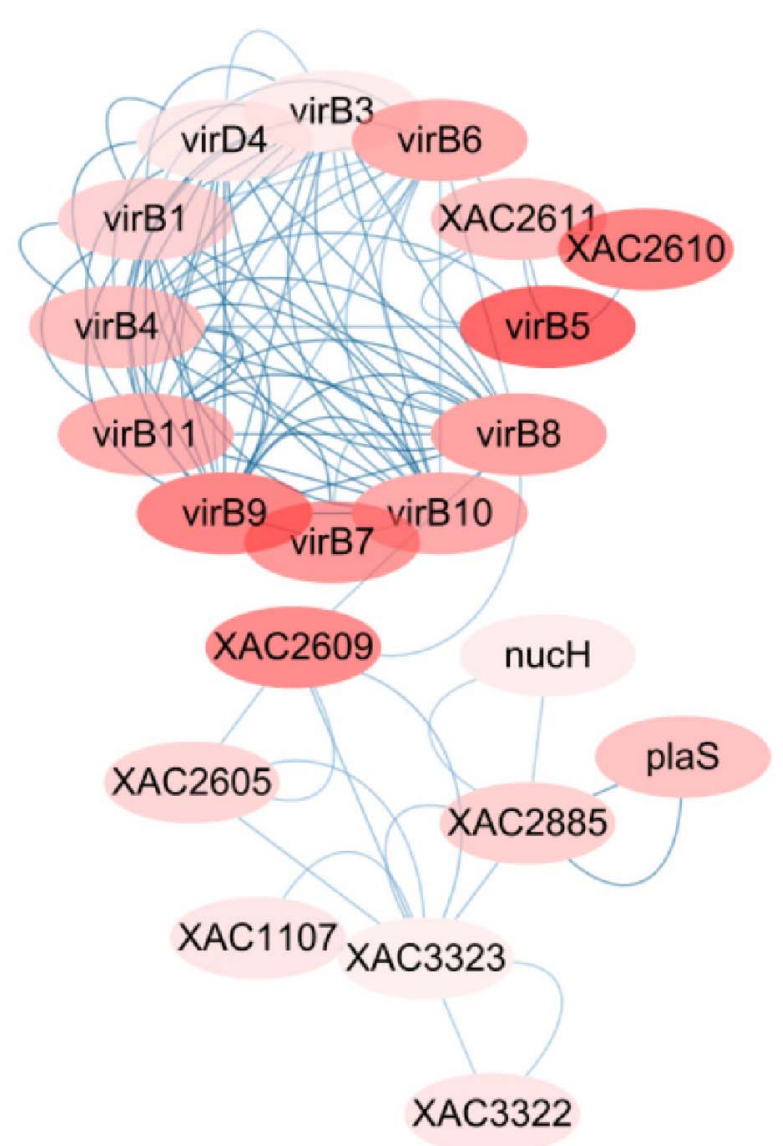

XAC3522

XAC3525
B

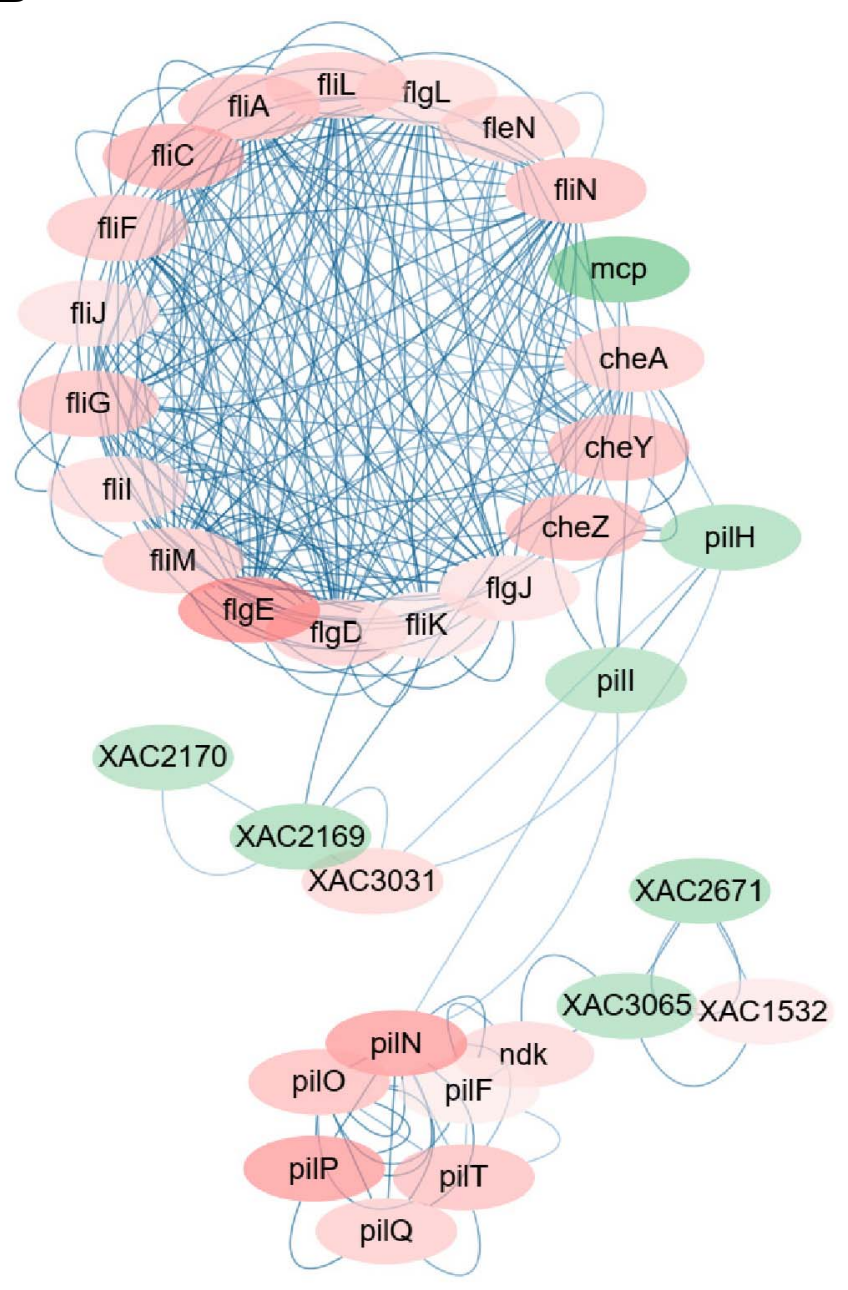

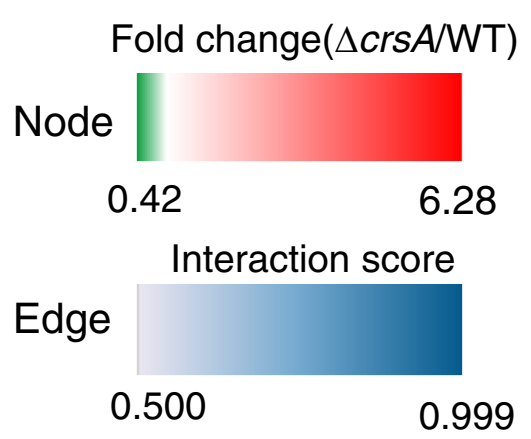

Fig. 2. Visualization of protein-protein association network for differentially expressed proteins (DEPs). All 284 DEPs were checked for putative interaction based on the STRING (v11) database. DEPs with the interaction score $\geq 0.50$ were extracted and imported into software Cytoscape (v3.8.0). Protein expression data and the interaction scores were used to color the nodes and the edges of this biological network, respectively. Only three striking clusters of interacting nodes (of 17 total) are shown here. A, Cluster of structural proteins involved in the type IV secretion system. B, Cluster of structural proteins involved in flagellar and pilus assembly. C, Cluster of proteins involved in xanthan gum biosynthesis. 
the RBS of virB5, which suggests that the binding of CsrA can prevent the docking of $30 \mathrm{~S}$ ribosomal subunit, thus mediating translational repression.

CsrA plays a role in motility, exopolysaccharide production, and biofilm formation.

To verify the data obtained in our comparative proteome analysis, we tested the regulation of CsrA on motility, EPS production, and biofilm formation. We compared the motility of wildtype and $\Delta c s r A$ mutant strains and observed that deletion of csrA impaired motility in the tested conditions (Fig. 6A and B; Supplementary Fig. S1). Interestingly, a previous study demonstrated that motility in $X$. citri subsp. citri depends on EPS production (Gottig et al. 2009). In accordance with this report, mutation in gumD, which encodes an essential protein involved in xanthan gum biosynthesis, caused a reduction of the motility (Fig. 6A and B). Complementation of the csrA mutant restored the motility phenotype to that observed in the wild-type strain (Fig. 6A and B). These results indicated that CsrA may positively regulate the xanthan gum production. We further quantified the EPS production in supernatants of $X$. citri subsp. citri strains and observed that mutation of $c s r A$ decreased exopolysaccharide production by approximately threefold, whereas mutation of gumD reduced approximately fourfold compared with wild-type (Fig. 6C). The $\Delta c s r A$ complemented strain was able to restore the exopolysaccharide production to similar levels as in the wild-type strain. We also evaluated whether $\operatorname{csr} A$ is involved in regulation of biofilm formation in $X$. citri subsp. citri. Interestingly, the $\triangle c s r A$ strain showed higher biofilm formation on a glass surface than the wild-type strain, whereas the complementation strain was similar to that of the wild-type (Fig. 6D).

\section{DISCUSSION}

Translation repression and activation are two modes of CsrA regulation that enable bacteria to control gene expression and rapidly respond to external stimuli (Vakulskas et al. 2015). Our iTRAQ data revealed both positive and negative regulation by CsrA. While this is consistent with these two presumed modes of action, many of the observed regulatory effects may be caused indirectly, because CsrA affected the expression of numerous regulatory genes (Supplementary Table S2). We have further expanded knowledge of the target proteins that are under direct or indirect regulation by CsrA, which helps to explain the multiple physiological and phenotypical changes caused by the knockout of CsrA in Xanthomonas spp. Here, we demonstrated that CsrA regulates genes involved in xanthan gum biosynthesis, flagellum assembly and T4SS, and beyond. This study expands the regulatory network of CsrA and leads to the discovery of a novel CsrA-binding target RNA in $X$. citri subsp. citri.

A

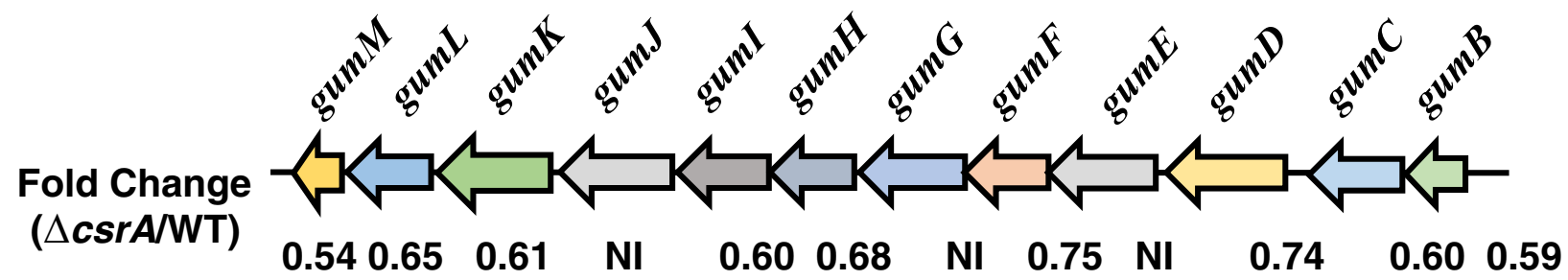

B
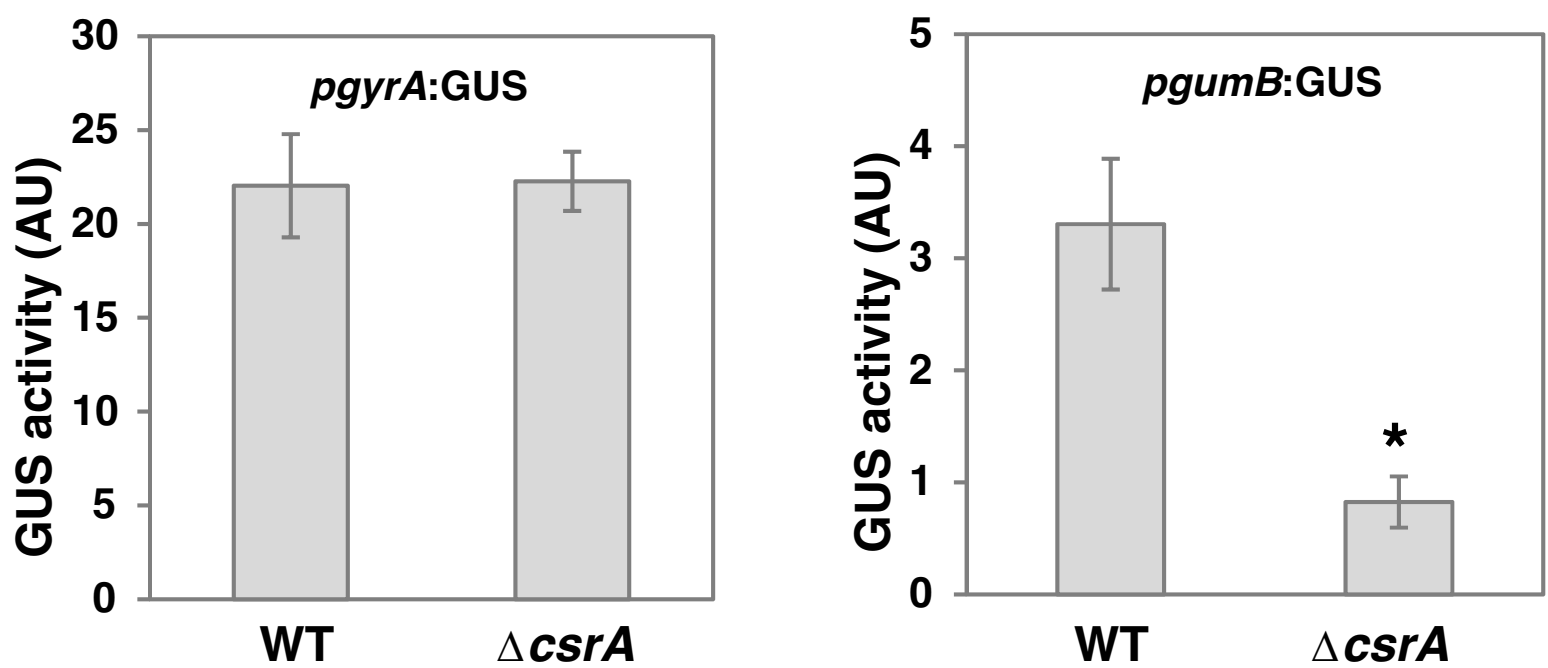

Fig. 3. CsrA positively regulates the gum gene cluster. A, Genomic organization of the xanthan gum gene cluster and its expression at the protein level in the $\Delta c s r A$ strain compared with the wild-type strain. $\mathrm{NI}=$ proteins that are not identified by isobaric tags for relative and absolute quantitation. B, Expression of gumB in the Xcc306 and $\Delta c s r A$ strains by $\beta$-glucuronidase (GUS) assay. gyrA was used as an endogenous control. Values represent means \pm standard deviation and asterisks indicate statistical significance, using Student's $t$ test $(P<0.05, n=3)$. This experiment was repeated twice in triplicates with similar results. 
A characteristic feature of xanthomonads is xanthan gum, which confers a mucoid appearance to the bacterial colonies (An et al. 2020; Büttner and Bonas 2010). Xanthan gum is not required for full pathogenicity of $X$. citri subsp. citri but contributes to its epiphytic survival and initial infection (Dunger et al. 2007; Li and Wang 2014). Xanthan gum is an important component of biofilms, which facilitate the formation of bacterial aggregates and proliferation in the intercellular space apoplast, and subsequent symptom development (Li and Wang 2011; Rigano et al. 2007). Deletion of csrA of X. citri subsp. citri caused significant reduction in production of EPS, which is consistent with previous studies, although gene expression change of gumB at the transcriptional level was not observed (Chao et al. 2008; Zhu et al. 2011). Here, our iTRAQ data clearly showed that CsrA positively controls the expression of the gumB operon at a translational level via an unknown mechanism. In addition to the CAP-like protein (Chen et al. 2010), the GntR family regulator HpaR1 (Su et al. 2016), and the transcriptional regulator CysB (Schulte et al. 2019), CsrA appears to be another regulator that controls xanthan gum biosynthesis in Xanthomonas genus. Intriguingly, CsrA was suggested to positively control exopolysaccharide amylovoran production, partly by repressing Lon protease, in Erwinia amylovora (Lee et al. 2018; Zhou et al. 2018). It remains to be determined whether a similar mechanism exists in $X$. citri subsp. citri.

Although the working modes vary in different species, it seems to be a common theme that CsrA regulates bacterial flagellum synthesis and motility. In E. coli, CsrA stabilizes the mRNA of the master regulatory genes $f h D C$ and, therefore, positively regulates flagellum biosynthesis (Wei et al. 2001; Yakhnin et al. 2013). In Bacillus subtilis, CsrA represses translation of the flagellin gene $h a g$ and interaction of FliW protein with CsrA inhibits this activity. This circuitry is essential to flagellin homeostasis and flagellar morphogenesis (Mukherjee et al. 2011; Yakhnin et al. 2007). In Legionella pneumophila, CsrA directly targets the mRNAs of two regulatory genes, fle $Q$ and $f l e R$, and inhibits their translation (Sahr et al. 2017). Intriguingly, in $X$. citri subsp. citri, the master regulatory gene $f l e Q$ was not altered either at the mRNA or protein levels in the $\triangle c s r A$ strain compared with that of wild-type strain Xcc306. CsrA positively regulates $\mathrm{PilH}$ but negatively regulates the expression of most pili genes. It was reported that $\mathrm{PilH}$ negatively regulates flagellum-dependent swimming but positively regulates pilidependent swarming motility in $X$. campestris pv. campestris (Qi et al. 2020). The mechanistic understanding of how CsrA regulates flagellar and pili genes needs further elucidation. The $\triangle$ csrA mutation in Xanthomonas spp. causes the loss of motility but also leads to an increase in expression of flagellum genes. This observation might be partially explained by the significant reduction in xanthan gum, since it provides an appropriate fluid microenvironment for motility in specific conditions (Harshey 2003). Consistent with this reasoning, mutation of gumD abolished the motility of $X$. citri subsp. citri in the motility assay. In addition, the csrA mutant appears to be more sticky on the glass wall than the wild-type $X$. citri subsp. citri, which might further explain the effect of CsrA on controlling both motility and sessile behavior. Moreover, the effect of CsrA on regulating other factors in $X$. citri subsp. citri that may also be

A
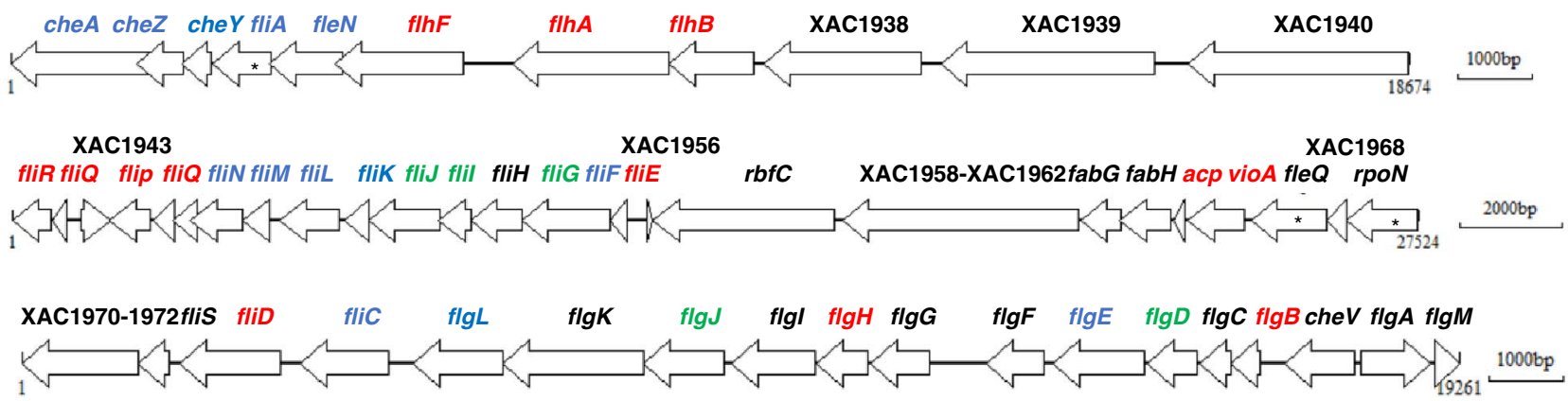

B

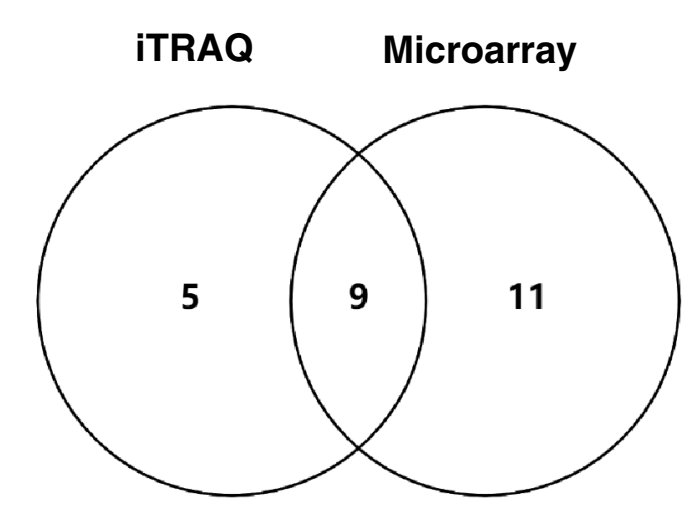

C

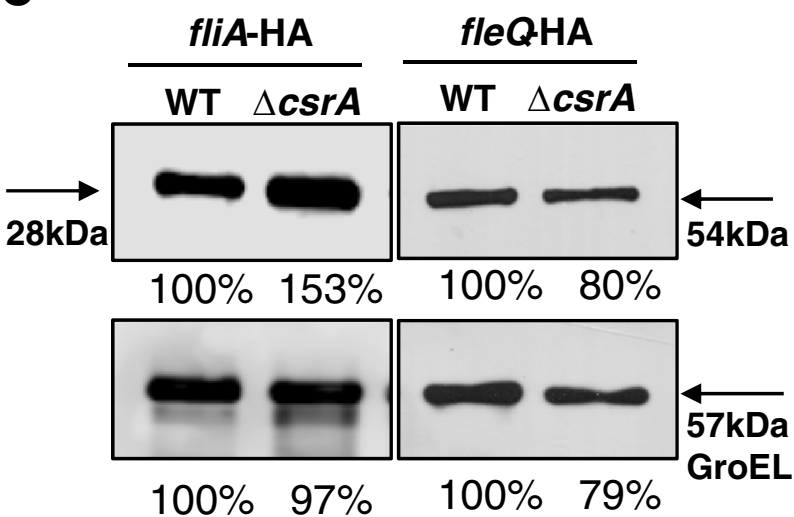

Fig. 4. CsrA negatively regulates flagellum assembly genes. A, Genomic organization and gene expression of flagellum assembly genes in the $\Delta c s r A$ strain compared with the wild-type strain. Upregulated genes at both the transcriptional and protein level are in blue, genes upregulated only at protein level are in green, genes upregulated only at transcriptional level are in red, and genes not changed at transcriptional or protein level are in black. Asterisks indicate master regulatory genes. B, Venn diagram of upregulated flagellar assembly genes revealed by isobaric tags for relative and absolute quantitation and microarray. C, Quantification of FleQ and FliA by Western blot. GroEL was used as an endogenous control. Relative band intensities were quantified by ImageJ (v1.52) and are shown at the bottom of each band. 
A

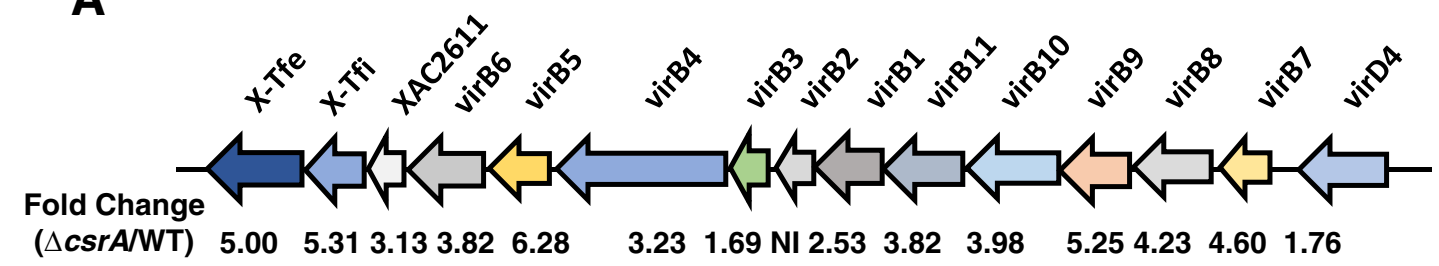

B

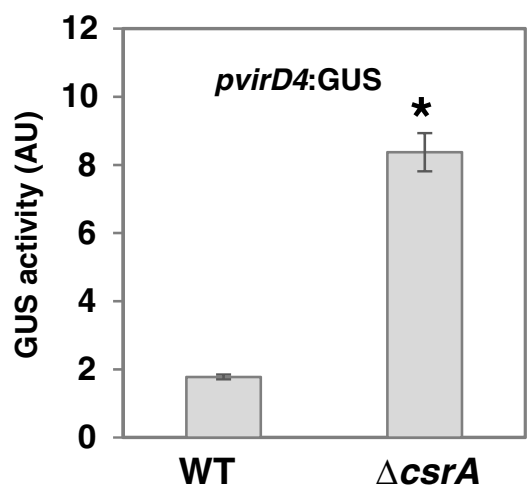

D

$\mathbf{E}$
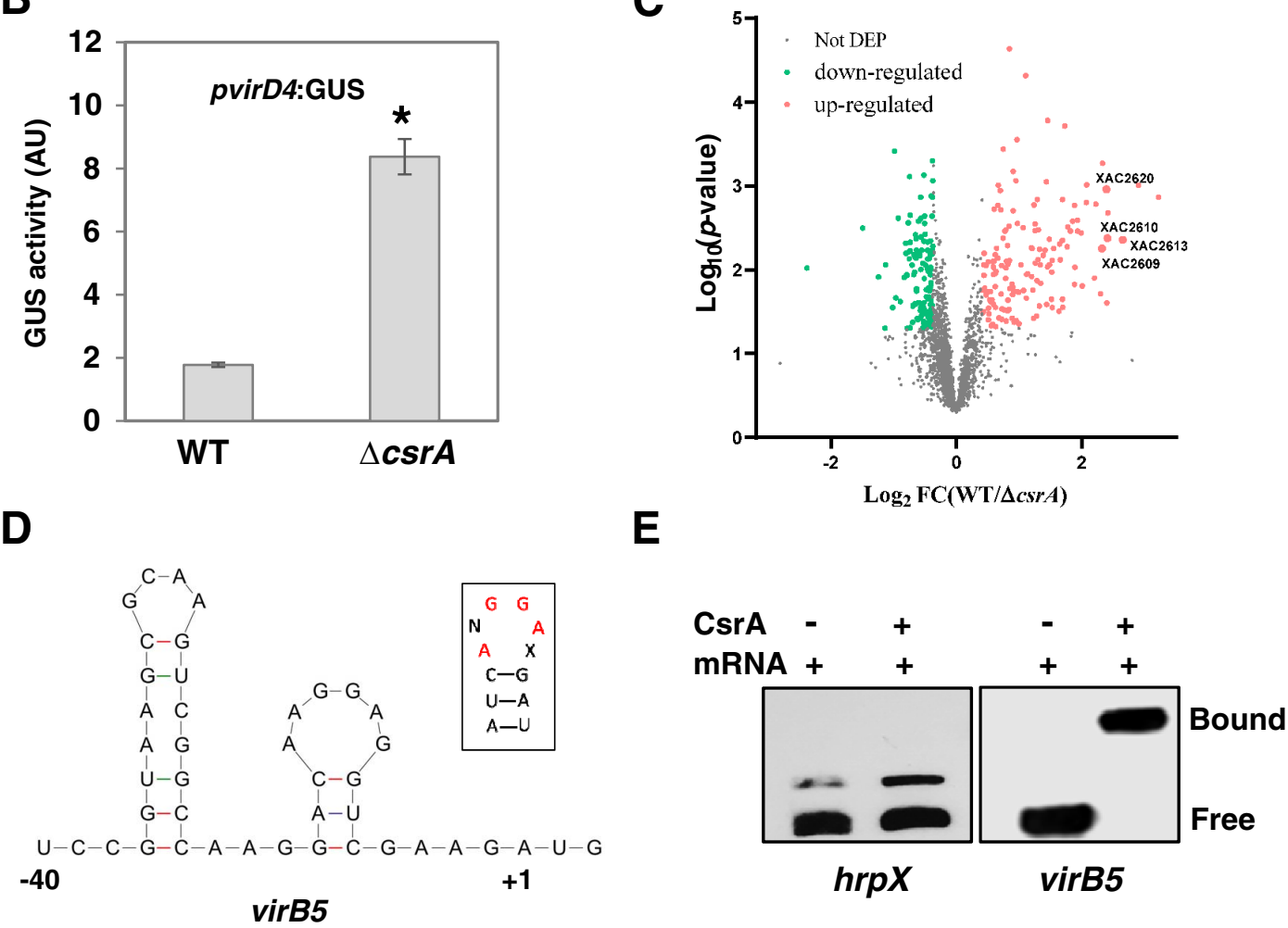

$\mathbf{F}$

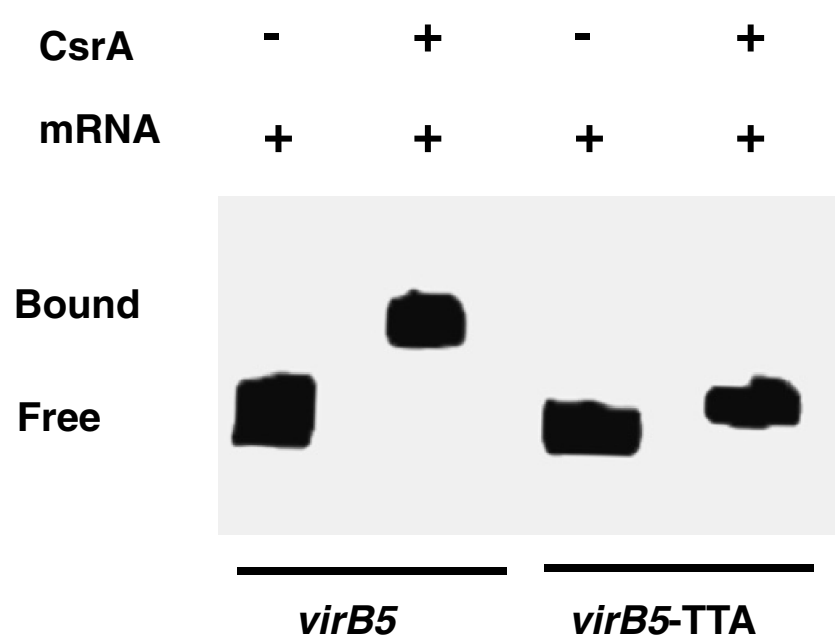

Fig. 5. CsrA negatively regulates the type IV secretion system (T4SS) and its effectors. A, Genomic organization of the T4SS gene cluster and its expression changes at protein level. NI = not identified by isobaric tags for relative and absolute quantitation; X-Tfe = Xanthomonadaceae T4SS effector; $\mathrm{X}$-Tfi = Xanthomonadaceae T4SS immunity protein. B, Expression of virD4 in Xcc306 and $\Delta c s r A$ strains by $\beta$-glucuronidase (GUS) assay. Values represent means \pm standard deviation and asterisks indicate statistical significance, using Student's $t$ test $(P<0.05, n=3)$. C, Overview of differentially expressed proteins (DEPs) by volcano plot. Four T4SS-associated genes of interest are annotated. D, Secondary structure prediction of the potential target region of virB5. A typical CsrA-binding site is shown inside the box. $+1=$ translational start site (TTS). E, Gel-shift assay for interaction between CsrA protein and the potential target region of virB5. The length of virB5 transcript is $118 \mathrm{nt}$. The 126-nt transcript from the $h r p X$ coding region was used as a negative control. F, RNA mobility shift assays for interaction between CsrA protein and wild type and mutated virB5 RNA probe. The virB5-TTA transcript was constructed by mutagenizing the putative binding site GGA to TTA. 
involved in flagellum biogenesis and function needs to be further investigated.

It only recently has been revealed that CsrA contributes to homeostasis of the bactericidal T4SS by maintaining a constant though partial repression of the $v i r B$ operon via direct translation inhibition of virB7 (Cenens et al. 2020). Consistent with the previous study, our proteomic data showed that knockout of csrA caused a substantial upregulation of most genes of the virB operon. Interestingly, virB5 was the most upregulated gene of the virB operon. RNA secondary structure prediction demonstrated that the untranslated leader sequence of virB5 contains the features of a typical CsrA-binding motif. Furthermore, a gelshift assay verified the interaction between CsrA and the leader sequence of virB5. Unlike virB7, virB5 is located in the middle of the virB operon. Similarly, it has been reported that CsrA can act on an internal gene of an operon (Pannuri et al. 2012) or more than one target of the same pathway (Andrade et al. 2014). Our results thereby indicate that CsrA negatively affects the levels of the T4SS-associated proteins by directly inhibiting the translation of both virB7 and virB5.

Importantly, the iTRAQ analysis identified 248 DEPs that were not identified by transcriptome analysis (Andrade et al. 2014). This is almost certainly because iTRAQ identifies CsrA targets at the protein level, whereas microarray analysis detects targets at the mRNA level. The iTRAQ data suggest that CsrA regulates eight transcriptional regulators (ColR, GacA, GlpR, KdgR, MoxR, $\mathrm{PilH}, \mathrm{RecX}$, and $\mathrm{YgiX}$ ) that further expand its regulatory spectrum and are predicted to contribute to its broad regulatory effects on numerous physiological processes and virulence traits in Xanthomonas spp. Among them, ColR plays multiple roles in the pathogenicity of $X$. citri subsp. citri, including regulating multiple hrp genes, biofilm formation, LPS production, and catalase activity (Yan and Wang 2011). GacA is involved in chemotaxis but does not have a significant effect on pathogenicity in Xanthomonas spp. (Yang et al. 2007). KdgR is an IclR family transcriptional regulator that inhibits virulence mainly by repressing expression of $h r p$ genes in X. oryzae pv. oryzae (Lu et al. 2011). Interestingly, CsrA is under positive control of $\mathrm{KdgR}$ in Erwinia carotovora subsp. carotovora (Hyytiäinen et al. 2001), indicating a complex regulatory system between them. RecX inhibits both RecA recombinase and coprotease activities through direct physical interaction (Pagès et al. 2003). The mechanistic understanding of the interactions between CsrA and these regulators is largely unknown and needs further investigation. In addition, CsrA regulates the levels of seven TonB-dependent receptors, four outer membrane proteins, two ferric enterobactin receptors, and many other gene products
A

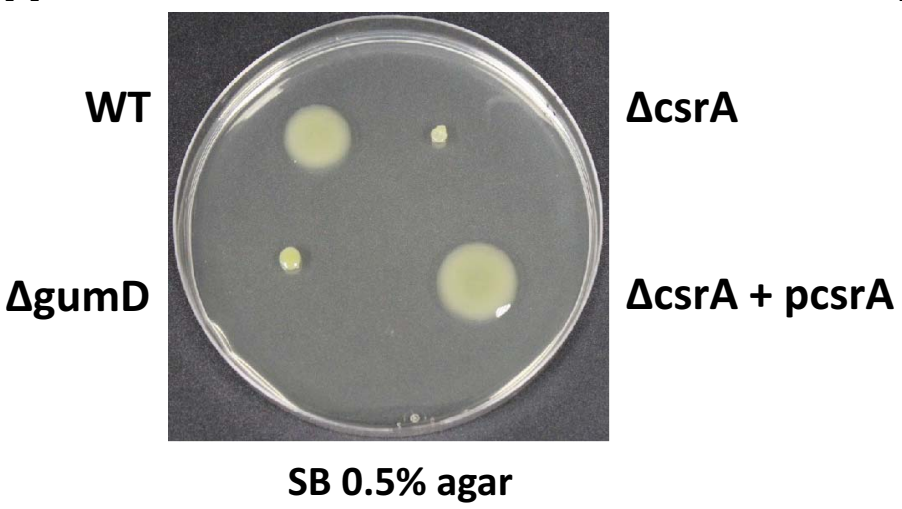

C

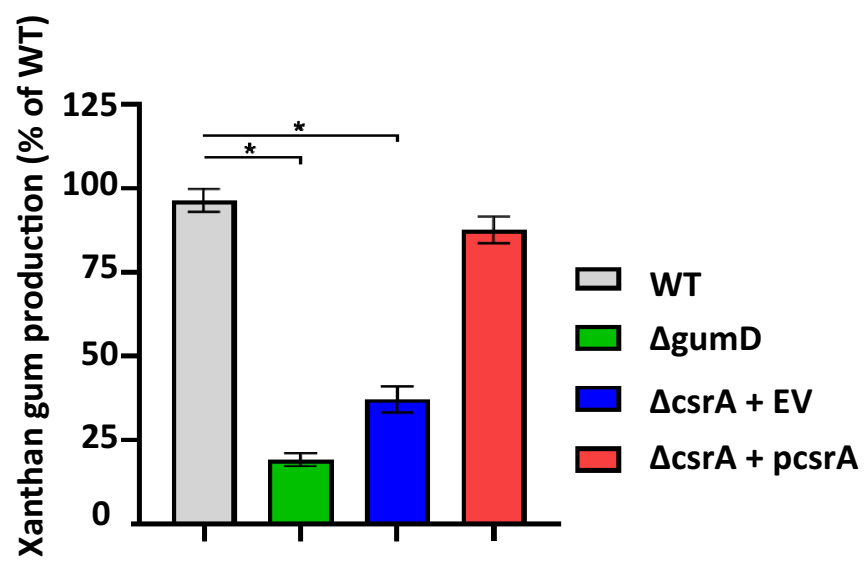

B

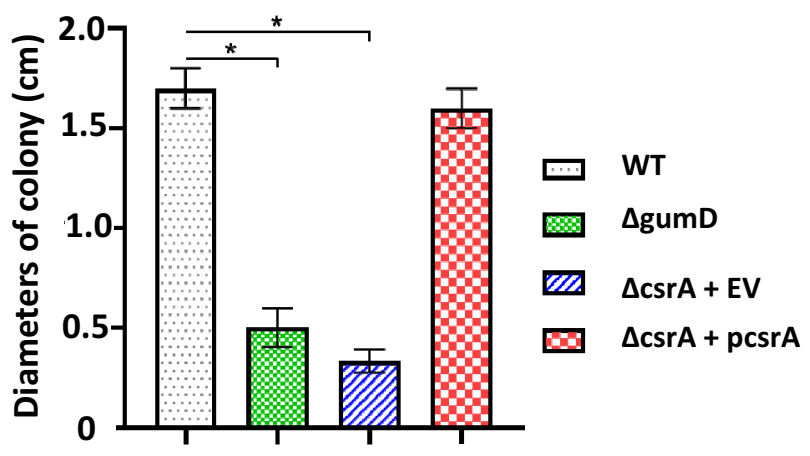

D

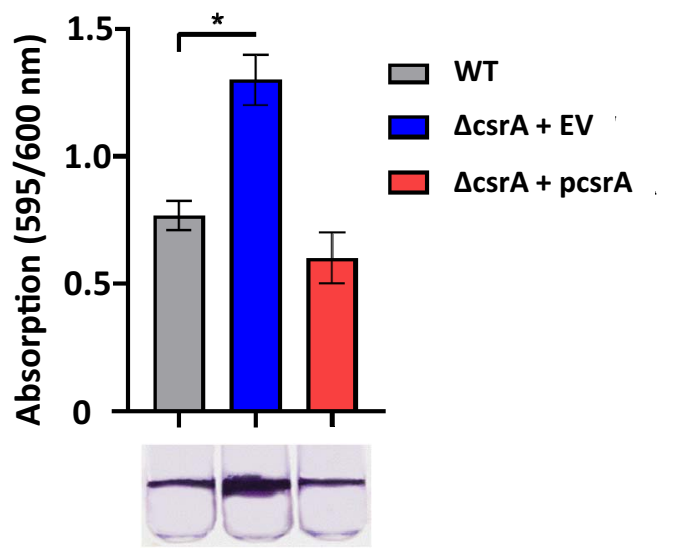

Fig. 6. CsrA regulates the motility, extracellular polysaccharides (EPS) production and biofilm formation in Xanthomonas citri subsp. citri. A, Motility assay on $0.5 \%$ Silva Buddenhagen $(\mathrm{SB})$ agar plates. Cells were spotted and experiments were analyzed after $48 \mathrm{~h}$ of incubation at $28^{\circ} \mathrm{C}$. B, Measurements of the diameters of cell spread on plates after $48 \mathrm{~h}$ of incubation at $28^{\circ} \mathrm{C}$. Values are expressed as the means \pm standard deviation of four independent biological replicates. C, EPS production by X. citri subsp. citri strains. Mean values \pm standard deviation derived from two independent experiments with three biological replicates each are shown. D, Biofilm formation of X. citri subsp. citri strains on a glass surface was assessed. Cells were grown in rich medium at $28^{\circ} \mathrm{C}$ for $72 \mathrm{~h}$, then biofilms were stained by crystal violet (CV) and were solubilized in 30\% acetic acid. Ratio A (595/ $600 \mathrm{~nm}$ ) represents the CV quantification and normalization by culture optical density. The means of three biological replicates and standard deviation values are shown. An asterisk $\left(^{*}\right)$ indicates significant difference based on one-way analysis of variance with Bonferroni $(P<0.001)$ compared with the wild-type $X$. citri subsp. citri strain (WT), $\Delta$ gumD and gumD mutant strain, $\Delta$ csrA and $c s r A$ mutant strain carrying the empty vector, and $\Delta$ csrA + pcsrA and complemented strain 
that span a broad spectrum of features, which need further characterization. Intriguingly, altered trends in expression of seven hrp structural genes were identified by iTRAQ, with only one gene, $H r p F$, having a $P$ value $<0.05$, whereas $24 \mathrm{hrp}$ structural genes were identified to be differentially regulated by CsrA in the microarray data (Andrade et al. 2014). This likely results from limited sensitivity of iTRAQ (Bacchor et al. 2019), which needs to be taken into consideration for future studies.

In summary, we found that CsrA regulates the levels of proteins involved in xanthan gum biosynthesis, flagellum assembly, and T4SS biogenesis and function. CsrA is also known to positively regulate T3SS and its effectors by stabilizing the transcript of $h r p G$. This study likewise identified many new targets of CsrA that may give rise to new research questions that further enhance our understanding of the vital function of CsrA.

\section{MATERIALS AND METHODS}

\section{Strains, plasmids, and culture conditions.}

Strains and plasmids used in this study are listed in Table 3. E. coli cells were cultured in lysogeny broth medium at $37^{\circ} \mathrm{C}$. Xanthomonas strains were cultured in nutrient broth (NB) medium and on nutrient agar (NA) plates at $28^{\circ} \mathrm{C}$. For induction of hrp genes, $X$. citri subsp. citri strains were grown in XVM2 medium (Wengelnik and Bonas 1996). When required, media were supplemented with antibiotics as follows: ampicillin,100 $\mu \mathrm{g} / \mathrm{ml}$; kanamycin, $50 \mu \mathrm{g} / \mathrm{ml}$; or gentamycin, $10 \mu \mathrm{g} / \mathrm{ml}$.

Oligonucleotides used are listed in the Supplementary Table S6 and restriction digestion and DNA ligation were performed in accordance with manufacturer instructions (New England Biolabs). To construct the gumD deletion mutant, approximately $1 \mathrm{~kb}$ of the upstream and downstream regions of the target gene were amplified by PCR from $X$. citri subsp. citri genomic DNA and the two fragments were fused by PCR, to produce an in-frame deletion (Andrade et al. 2014). The generated fragment was then cloned into the EcoRI restriction site of the pNPTS138 suicide vector, generating the construct pNPTS-gumD (Table 3). The construct was introduced into $X$. citri subsp. citri by electroporation, and the wild-type gumD was replaced by the deleted version after two recombination events, as described previously (Andrade, et al. 2014). The gumD deletion mutant were confirmed by PCR.

\section{iTRAQ and identification of DEPs.}

iTRAQ procedures were conducted as previously described (Klee et al. 2018). Briefly, the wild-type strain Xcc306 and its $\Delta c s r A$ derivative (four biological replicates per strain) were cultured in defined XVM2 medium and were harvested at the exponential phase of growth (optical density at $600 \mathrm{~nm}\left[\mathrm{OD}_{600}\right]=$ $0.35)$. The proteins $(100 \mu \mathrm{g})$ from each sample were digested with trypsin and were labeled with 8-plex isobaric tags. Wildtype replicates were labeled with 113,114, 115, and116 tags, and $\Delta c s r A$ replicates with $117,118,119$, and 121 tags. Labeled peptides were combined and further fractionated, using SCX chromatography on an Agilent HPLC system 1100. Peptide analyses on the Q-Exactive Plus Mass Spectrometer (Thermo Fisher Scientific) were conducted at the Interdisciplinary Center for Biotechnology Research of the University of Florida. Protein identification and quantification were carried out, using MaxQuant (v1.6), against the proteome of Xcc306 downloaded from UniProt database (Tyanova et al. 2016). Proteins with a ratio $(\Delta c s r A / W T)<0.77$ or $>1.3$ and $P$ value $<0.05$ by student's $t$ test were considered to be DEPs.

Table 3. Strains and plasmids used in this study ${ }^{a}$

\begin{tabular}{|c|c|c|}
\hline Types/strains & Relevant characteristic & Reference or source \\
\hline \multicolumn{3}{|l|}{ Escherichia coli } \\
\hline \multirow[t]{2}{*}{ BL21(DE3) } & fhuA2 [lon] ompT gal ( $\lambda \mathrm{DE} 3)[\mathrm{dcm}] \Delta \mathrm{hsdS}$ & \multirow{2}{*}{ Novagen } \\
\hline & $\begin{array}{l}\lambda \text { DE3 }=\lambda \text { sBamHIo } \Delta E c o \text { RI-B int::(lacI::PlacUV5::T7 } \\
\text { gene1) i21 } \Delta \text { nin5 }\end{array}$ & \\
\hline S-17-1 $\lambda$ pir & RK2 tra regulon, pir, host for pir-dependent plasmid pOK1 & Simon et al. 1983 \\
\hline \multicolumn{3}{|l|}{ Xanthomonas citri subsp. Citri } \\
\hline Xcc306 & Syn. $X$. axonopodis pv. citri 306 ; wild type, Rif $^{\mathrm{r}}$ & da Silva et al. 2002 \\
\hline Xcc306 fliA HA & HA tag insertion strain in the background of Xcc 306 , Rif ${ }^{\mathrm{r}}$ & This study \\
\hline Xcc306_fleQ_HA & HA tag insertion strain in the background of $\mathrm{Xcc} 306$, Rif $^{\mathrm{r}}$ & This study \\
\hline $\mathrm{Xcc} \Delta \mathrm{gumD}$ & The gumD deletion mutant of $X$. citri subsp. citri & This study \\
\hline \multicolumn{3}{|c|}{ 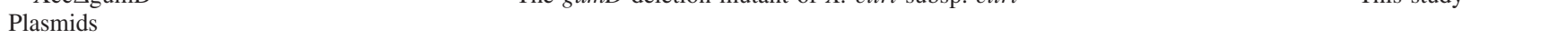 } \\
\hline pGUS & $\begin{array}{l}\text { pBBR1MCS- } 5 \text { derivative containing gus gene followed by } \\
\text { T7 terminator cloned in reverse orientation of lac } \\
\text { promoter. }\end{array}$ & Teper et al. 2019 \\
\hline pGUS:pgyrA & $\begin{array}{l}\text { pGUS derivative. The } 189 \text { bp upstream region of XAC1631 } \\
\text { was cloned upstream to gus, } \mathrm{Gn}^{\mathrm{R}}\end{array}$ & Teper et al. 2019 \\
\hline pGUS:pgumB & $\begin{array}{l}\text { pGUS derivative. The } 527 \text { bp upstream region of XAC2585 } \\
\text { was cloned upstream to gus, } \mathrm{Gn}^{\mathrm{R}}\end{array}$ & This study \\
\hline pGUS:pvirD4 & $\begin{array}{l}\text { pGUS derivative. The } 268 \text { bp upstream region of XAC2623 } \\
\text { was cloned upstream to gus, } \mathrm{Gn}^{\mathrm{R}}\end{array}$ & This study \\
\hline pOK1 & sacB sacQ mobRK2 oriR6K, suicide vector, $\mathrm{Sp}^{\mathrm{R}}$ & Huguet et al. 1998 \\
\hline pOK1:fliA_HA & $\begin{array}{l}\text { pOK1 derivative containing the fliA in frame with } 3^{\prime} \text { HA } \\
\text { tag, } \mathrm{Sp}^{\mathrm{R}}\end{array}$ & This study \\
\hline pOK1:fleQ_HA & $\begin{array}{l}\text { pOK1 derivative containing the fle } Q \text { in frame with } 3^{\prime} \text { HA } \\
\text { tag, } \mathrm{Sp}^{\mathrm{R}}\end{array}$ & This study \\
\hline pET-28a:CsrA & $\begin{array}{l}\text { pET-28a derivative containing } \operatorname{crs} A \text { downstream } \mathrm{T} 7 \\
\text { promoter, } \mathrm{Kn}^{\mathrm{R}}\end{array}$ & Andrade et al. 2014 \\
\hline pNPTS-gumD & $\begin{array}{l}\text { The suicide vector pNPTS } 138 \text { containing } 1 \mathrm{~kb} \text { of the } \\
\text { upstream and downstream regions of gumD to produce an } \\
\text { in-frame deletion mutant of gumD }\end{array}$ & This study \\
\hline pMD19 & T-vector for PCR cloning, $\mathrm{Ap}^{\mathrm{r}}$ & Takara \\
\hline pMD19-5UTRvirB5 & $5^{\prime}$ UTR of virB5 with T7 promoter cloned in $\mathrm{pMD} 19, \mathrm{Ap}^{\mathrm{r}}$ & This study \\
\hline pMD19-5UTRvirB5-TTA & $5^{\prime}$ UTR of virB5 mutated from GGA to TTA, Ap ${ }^{\mathrm{r}}$ & This study \\
\hline
\end{tabular}




\section{Bioinformatic analysis.}

For enrichment analysis, a COG functional category was assigned to the protein-coding genes of $X$. citri subsp. citri using eggNOG-mapper (v2) (Huerta-Cepas et al. 2017). Functional enrichment analysis for either differentially expressed genes or DEPs was performed using Fisher's exact test within the R environment (v4.0.0) (Abatangelo et al. 2009). In addition, clusterProfiler (v3.16.1) was used for pathway enrichment analysis (Yu et al. 2012). For PPI analysis, all 284 DEPs were checked for putative interactions based on a STRING (v11.0) database (Szklarczyk et al. 2019). DEPs with an interaction score $\geq 0.5$ were extracted. These data, including interaction scores and a gene expression table, were imported into software Cytoscape (v3.8.0) to construct biomolecular interaction networks (Shannon et al. 2003). For RNA secondary structure prediction, the software Mfold web server was used (Zuker 2003).

\section{Western blot.}

To label proteins at the native genomic loci, an HA tag (YPYDVPDYA) coding sequence was incorporated into the $3^{\prime}$ end of FliA- and FleQ-coding sequence by PCR, according to the designed primers (Supplementary Table S6). For each gene, the two amplicons were combined together into one fragment, using overlap PCR. After restriction enzyme digestion, the whole fragment containing the HA tag coding sequence and its flanking regions was inserted into the suicide vector pOK1. Recombinant pOK1 plasmid was transferred to the wild-type Xcc306 and $\Delta$ csrA strains by electroporation, and markerless replacement mutants were produced, using a two-step sucrose counter-selection method (Zhang et al. 2019a). Wild-type strain Xcc306 and the $\Delta c s r A$ strain containing HA-tag were cultured in XVM2 medium. At exponential phase $\left(\mathrm{OD}_{600}=0.35\right)$, bacteria were harvested, were ruptured by sonication, and were centrifuged at $14,000 \mathrm{rpm}$ for $30 \mathrm{~min}$ under $4^{\circ} \mathrm{C}$ using a centrifuge (Eppendorf). Protein extracts were quantified by the Bradford method at $595 \mathrm{~nm}$, using a Bio-Rad protein assay kit (Bio$\mathrm{Rad})$. Equal amounts of proteins were loaded, were separated by $12 \%$ sodium dodecyl sulfate-polyacrylamide gel electrophoresis, and were transferred to a nitrocellulose membrane (GE Healthcare). The membrane was then incubated with anti-HA tag antibody (Roche), followed by the anti-immunoglobulin $\mathrm{G}$ horseradish peroxidase-conjugated antibody (Abcam). As a control, immunoblotting was carried out for the same protein extracts using antigroEL antibody (Abcam). Immunoblots were developed with SuperSignal West Pico Chemiluminescent Substrate (Thermo Fisher Scientific) and were detected by C-DiGit Blot Scanner (LI-COR Biosciences).

\section{GUS assay.}

To generate GUS reporter plasmids, the putative promoter region, untranslated leader segment, plus a small portion of the coding region of the tested genes was amplified with designed primers (Supplementary Table S6) and was cloned into pGUS vector (Teper et al. 2019). Recombinant pGUS vectors were transferred into wild-type Xcc306 and $\Delta c s r A$ strains by electroporation. GUS activity was quantified as described previously (Wang et al. 2006a and b; Zhang et al. 2019a). Briefly, bacterial cells cultured in the XVM2 medium were harvested and were resuspended in PBS buffer. After sonication, $20 \mu \mathrm{l}$ of clear supernatant was added to $80 \mu \mathrm{l}$ of phosphate buffered saline (PBS) containing $1.25 \mu \mathrm{M}$ p-nitrophenyl $\beta$-D-glucopyranoside in a 96-well plate. Stop buffer $\left(100 \mu \mathrm{l}\right.$ of $\left.0.4 \mathrm{M} \mathrm{Na}_{2} \mathrm{CO}_{3}\right)$ was added to stop the reaction immediately when yellow color appeared during incubation at $37^{\circ} \mathrm{C}$ and the reaction time was also recorded. The absorbance of reaction solution was measured at $405 \mathrm{~nm}$ and protein amount was calculated by the Bradford method at $595 \mathrm{~nm}$, using a Bio-Rad protein assay kit (Bio-
Rad). GUS activity was quantified by arbitrary units and was determined as $\mathrm{A}_{405} /$ (time in $\min \times \mathrm{A}_{595} \times 0.02$ ). The experiment was repeated at least twice in triplicates with similar results.

\section{In vitro transcription.}

Briefly, to produce the DNA templates for the targeted mRNA transcripts, two rounds of PCR amplification were performed to fuse the T7 promoter sequence with the DNA sequence for the targeted mRNA transcripts, using the specific primer pairs (Supplementary Table S6). The transcripts of $h r p X$ and virB5 were produced in vitro using the SP6/T7 transcription kit (Roche) and Biotin RNA labeling kit (Roche), following manufacturer instructions.

To generate the mutated virB5-TTA transcript, the 5' UTR of virB5 was cloned into pMD19 T-vector and the predicted GGA binding site was changed to TTA, using a Q5 site-directed mutagenesis kit (New England Biolabs), which was used for in vitro transcription.

All transcripts were purified using the Zymoclean gel RNA recovery kit (Zymo Research) and were resuspended in diethyl pyrocarbonate water. RNA product was quantified with NanoDrop (NanoDrop Technologies).

\section{Purification of CsrA.}

The purification of CsrA was described previously (Andrade et al. 2014). Briefly, the recombinant 6 His-CsrA protein was overexpressed in E. coli BL21 (DE3) (Novagen) by the addition of $1 \mathrm{mM}$ isopropyl- $\beta$-D-thiogalactopyranoside to cells at midexponential phase. Bacterial cells were harvested $4 \mathrm{~h}$ later and were resuspended in lysis buffer containing $50 \mathrm{mM} \mathrm{NaH} \mathrm{PO}_{4}$ (pH 8.0), $300 \mathrm{mM} \mathrm{NaCl}, 10 \mathrm{mM}$ imidazole, and $1 \mathrm{mg}$ lysozyme. Ruptured by sonication, cell-free extract was prepared by centrifugation at $14,000 \times g$ at $4^{\circ} \mathrm{C}$ for $45 \mathrm{~min}$. 6 His-CsrA was purified by Ni-NTA affinity chromatography (Pierce) according to manufacturer recommendations. The protein-containing fractions were concentrated, and the buffer was exchanged with $10 \mathrm{mM}$ HEPES (pH 7.3), $20 \mathrm{mM} \mathrm{KCl}, 1 \mathrm{mM} \mathrm{MgCl}_{2}, 1 \mathrm{mM}$ dithiothreitol, and $10 \%$ glycerol. The protein concentration was estimated by the Bradford method, using a Bio-Rad protein assay kit (Bio-Rad).

\section{RNA-EMSA.}

Briefly, the CsrA-RNA binding reaction mixtures were prepared using a LightShift chemiluminescent RNA EMSA kit (Thermo Fisher Scientific), following the manufacturer instructions. A total volume of $20 \mu \mathrm{l}$ of reaction mixture contained approximately $100 \mathrm{nM} 6 \mathrm{His}-\mathrm{Csr}$ A protein and $2 \mathrm{nM}$ Biotinlabeled RNA and $1 \times$ binding buffer (10 mM HEPES, pH 7.3, $5 \%$ glycerol, $0.1 \mu \mathrm{g}$ per microliter of yeast tRNA). After incubation for $20 \mathrm{~min}$ at room temperature, $5 \mu \mathrm{l}$ of $5 \times$ loading buffer was added to the mixture. Then, $5 \mu \mathrm{l}$ of the resulting mixture was resolved using $6 \%$ native polyacrylamide gels in $0.5 \times$ Trisborate-EDTA buffer. RNA on the gel was then transferred to a nylon membrane, followed by exposure to $254 \mathrm{~nm}$ of UV light for crosslinking. Chemiluminescent signals were visualized by C-DiGit Blot Scanner (LI-COR Biosciences).

\section{Motility, exopolysaccharide production, and biofilm assays.}

Bacterial swimming motility was tested using a semisolid NA plate containing $0.3 \%$ agar. Bacteria were grown in NB overnight with shaking at $200 \mathrm{rpm}$ using a platform shaker (New Brunswick Scientific) and were then centrifuged down, were washed, and were diluted to $\mathrm{OD}_{600}=0.5$ in sterile water. A $5-\mu \mathrm{l}$ suspension of each strain was spotted on the center of the plates and were incubated at $28^{\circ} \mathrm{C}$. Plates were photographed after 48 $\mathrm{h}$. The assay was repeated three times independently in triplicates with similar results. 
For the motility assay, bacteria were grown overnight in NB medium, and $2 \mu \mathrm{l}$ of bacterial culture $\left(10^{6} \mathrm{CFU} / \mathrm{ml}\right)$ was then plated onto Silva Buddenhagen medium (per liter: $5 \mathrm{~g}$ of sucrose, $5 \mathrm{~g}$ of yeast extract, $5 \mathrm{~g}$ of peptone, and $1 \mathrm{~g}$ of glutamic acid, $\mathrm{pH} 7.0$ ) plus $0.5 \%$ (wt/vol) agar (BD Difco). Plates were incubated at $28^{\circ} \mathrm{C}$ for $48 \mathrm{~h}$. Motility analysis was assessed by examining the circular halo formed by the bacteria. The diameters of the circular halos formed by each strain were measured. The diameter measurements were statistically analyzed using one-way analysis of variance (ANOVA) with Bonferroni $(P<$ 0.001 ) by comparing with the wild-type strain and values were expressed as the means \pm standard deviations of four independent biological replicates.

Formation of biofilms on glass surfaces was examined as described previously, with modifications (Guo et al. 2019; Zhang et al. 2019b). Briefly, the wild-type, mutant, and complemented cells were grown in $2 \times$ TY medium (per liter: $16 \mathrm{~g}$ of tryptone, $10 \mathrm{~g}$ of yeast extract, and $5 \mathrm{~g}$ of $\mathrm{NaCl}$ ) overnight at $28^{\circ} \mathrm{C}$ and $180 \mathrm{rpm}$. Bacterial cells were diluted in fresh $2 \times$ TY medium to $\mathrm{OD}_{600}$ adjusted to 0.1 (UV/Vis Spectrometer Lambda Bio; Perkin Elmer). A volume of $1.5 \mathrm{ml}$ of adjusted bacteria was placed in the glass tubes and was incubated at $28^{\circ} \mathrm{C}$ without agitation. After 3 days, bacterial growth was checked by measuring the $\mathrm{OD}_{600}$, and the culture was removed using a pipette. After repetitive washes with sterile water, the adhered cells were stained with $0.1 \%$ (wt/vol) crystal violet $(\mathrm{CV})$ for $30 \mathrm{~min}$ at room temperature. After staining by $\mathrm{CV}$, the unbound stain was removed by water washing, and the CV-stained cells were solubilized in $30 \%$ acetic acid and were quantified by spectrophotometry at $600 \mathrm{~nm}$. Ratio A (595/600 nm) represents the CV quantification normalized by culture optical density. The means were obtained from three independent biological replicates and standard deviation values were calculated for each strain. Statistical analysis was performed by one-way ANOVA with Bonferroni $(P<$ 0.001 ) by comparing with the wild-type strain.

For exopolysaccharide quantification, bacterial cells were grown overnight at $28^{\circ} \mathrm{C}$ and $180 \mathrm{rpm}$ in $2 \times \mathrm{TY}$ medium. The bacteria concentrations were adjusted to $10^{8} \mathrm{CFU} / \mathrm{mL}$ and $1 \mathrm{~mL}$ was transferred to $50 \mathrm{~mL}$ of $2 \times \mathrm{TY}$ plus glucose $(2 \% \mathrm{wt} / \mathrm{vol})$. After $48 \mathrm{~h}$ of growth at $28^{\circ} \mathrm{C}$ and $180 \mathrm{rpm}$, bacterial cells were pelleted by centrifugation $(2,600 \times g$ for $8 \mathrm{~min})$ and three volumes of $100 \%$ ethanol were added to the supernatant. The crude xanthan gum was collected using a glass rod and was placed on a Petri dish to dry at $60^{\circ} \mathrm{C}$ for $24 \mathrm{~h}$. The assay was performed twice with three biological replicates in each experiment and was statistically analyzed using one-way ANOVA with Bonferroni $(P<0.001)$ by comparing with the wild-type strain.

\section{AUTHOR-RECOMMENDED INTERNET RESOURCE}

eggNOG-mapper: http://eggnog-mapper.embl.de/

\section{LITERATURE CITED}

Abatangelo, L., Maglietta, R., Distaso, A., D’Addabbo, A., Creanza, T. M., Mukherjee, S., and Ancona, N. 2009. Comparative study of gene set enrichment methods. BMC Bioinformatics 10:275.

An, S. Q., Potnis, N., Dow, M., Vorhölter, F. J., He, Y. Q., Becker, A., Teper, D., Li, Y., Wang, N., Bleris, L., and Tang, J. L. 2020. Mechanistic insights into host adaptation, virulence and epidemiology of the phytopathogen Xanthomonas. FEMS Microbiol. Rev. 44:1-32.

Andrade, M. O., Farah, C. S., and Wang, N. 2014. The posttranscriptional regulator $r s m A / c s r A$ activates T3SS by stabilizing the $5^{\prime}$ UTR of $h r p G$, the master regulator of hrp/hrc genes, in Xanthomonas. PLoS Pathog. 10:e1003945.

Babitzke, P., Lai, Y. J., Renda, A. J., and Romeo, T. 2019. Posttranscription initiation control of gene expression mediated by bacterial RNAbinding proteins. Annu. Rev. Microbiol. 73:43-67.
Babitzke, P., and Romeo, T. 2007. CsrB sRNA family: Sequestration of RNA-binding regulatory proteins. Curr. Opin. Microbiol. 10:156-163.

Bąchor, R., Waliczek, M., Stefanowicz, P., and Szewczuk, Z. 2019. Trends in the design of new isobaric labeling reagents for quantitative proteomics. Molecules 24:701.

Benjamini, Y., and Hochberg, Y. 1995. Controlling the false discovery rate: A practical and powerful approach to multiple testing. J. R. Stat. Soc. Ser. B. 57:289-300.

Büttner, D., and Bonas, U. 2010. Regulation and secretion of Xanthomonas virulence factors. FEMS Microbiol. Rev. 34:107-133.

Cenens, W., Andrade, M. O., Llontop, E., Alvarez-Martinez, C. E., Sgro, G. G., and Farah, C. S. 2020. Bactericidal type IV secretion system homeostasis in Xanthomonas citri. PLoS Pathog. 16:e1008561.

Chao, N.-X., Wei, K., Chen, Q., Meng, Q.-L., Tang, D.-J., He, Y.-Q., Lu, G.-T., Jiang, B.-L., Liang, X.-X., Feng, J.-X., Chen, B., and Tang, J.-L. 2008. The rsmA-like gene rsmA $A_{\mathrm{Xcc}}$ of Xanthomonas campestris pv. campestris is involved in the control of various cellular processes, including pathogenesis. Mol. Plant-Microbe Interact 21:411-423.

Chen, C. H., Lin, N. T., Hsiao, Y. M., Yang, C. Y., and Tseng, Y. H. 2010. Two non-consensus Clp binding sites are involved in upregulation of the gum operon involved in xanthan polysaccharide synthesis in Xanthomonas campestris pv. campestris. Res. Microbiol. 161:583-589.

Cui, K., He, L., Zhao, Y., Mu, W., Lin, J., and Liu, F. 2020. Comparative analysis of Botrytis cinerea in response to the microbial secondary metabolite benzothiazole using iTRAQ-based quantitative proteomics. Phytopathology.

da Silva, A. C. R. R., Ferro, J. A., Reinach, F. C., Farah, C. S., Furlan, L. R., Quaggio, R. B., Monteiro-Vitorello, C. B., Van Sluys, M. A., Almeida, N. F., Alves, L. M., do Amaral, A. M., Bertolini, M. C., Camargo, L. E., Camarotte, G., Cannavan, F., Cardozo, J., Chambergo, F., Ciapina, L. P., Cicarelli, R. M., Coutinho, L. L., Cursino-Santos, J. R., El-Dorry, H., Faria, J. B., Ferreira, A. J., Ferreira, R. C., Ferro, M. I., Formighieri, E. F., Franco, M. C., Greggio, C. C., Gruber, A., Katsuyama, A. M., Kishi, L. T., Leite, R. P., Lemos, E. G., Lemos, M. V., Locali, E. C., Machado, M. A., Madeira, A. M., Martinez-Rossi, N. M., Martins, E. C., Meidanis, J., Menck, C. F., Miyaki, C. Y., Moon, D. H., Moreira, L. M., Novo, M. T., Okura, V. K., Oliveira, M. C., Oliveira, V. R., Pereira, H. A., Rossi, A., Sena, J. A., Silva, C., de Souza, R. F., Spinola, L. A., Takita, M. A., Tamura, R. E., Teixeira, E. C., Tezza, R. I., Trindade dos Santos, M., Truffi, D., Tsai, S. M., White, F. F., Setubal, J. C., and Kitajima, J. P. 2002. Comparison of the genomes of two Xanthomonas pathogens with differing host specificities. Nature. 417:459-463.

Duan, S., Jia, H., Pang, Z., Teper, D., White, F., Jones, J., Zhou, C., and Wang, N. 2018. Functional characterization of the citrus canker susceptibility gene CsLOB1. Mol. Plant Pathol. 19:1908-1916.

Dubey, A. K., Baker, C. S., Romeo, T., and Babitzke, P. 2005. RNA sequence and secondary structure participate in high-affinity CsrARNA interaction. RNA 11:1579-1587.

Dugar, G., Svensson, S. L., Bischler, T., Wäldchen, S., Reinhardt, R., Sauer, M., and Sharma, C. M. 2016. The CsrA-FliW network controls polar localization of the dual-function flagellin mRNA in Campylobacter jejuni. Nat. Commun. 7:11667.

Dunger, G., Relling, V. M., Tondo, M. L., Barreras, M., Ielpi, L., Orellano, E. G., and Ottado, J. 2007. Xanthan is not essential for pathogenicity in citrus canker but contributes to Xanthomonas epiphytic survival. Arch. Microbiol. 188:127-135.

Duss, O., Michel, E., Diarra dit Konté, N., Schubert, M., and Allain, F. H. 2014. Molecular basis for the wide range of affinity found in Csr/Rsm protein-RNA recognition. Nucleic Acids Res. 42:53325346.

Edwards, A. N., Patterson-Fortin, L. M., Vakulskas, C. A., Mercante, J. W., Potrykus, K., Vinella, D., Camacho, M. I., Fields, J. A., Thompson, S. A., Georgellis, D., Cashel, M., Babitzke, P., and Romeo, T. 2011. Circuitry linking the $\mathrm{Csr}$ and stringent response global regulatory systems. Mol. Microbiol. 80:1561-1580.

Favaro, M. A., Molina, M. C., Roeschlin, R. A., Gadea, J., Gariglio, N., and Marano, M. R. 2020. Different responses in mandarin cultivars uncover a role of cuticular waxes in the resistance to citrus canker. Phytopathology 110:1791-1801.

Ference, C. M., Gochez, A. M., Behlau, F., Wang, N., Graham, J. H., and Jones, J. B. 2018. Recent advances in the understanding of Xanthomonas citri ssp. citri pathogenesis and citrus canker disease management. Mol. Plant Pathol. 19:1302-1318.

Ference, C. M., Manthey, J. A., Narciso, J. A., Jones, J. B., and Baldwin, E. A. 2020. Detection of phenylpropanoids in citrus leaves produced in response to Xanthomonas citri subsp. citri. Phytopathology 110: 287-296. 
Gottig, N., Garavaglia, B. S., Garofalo, C. G., Orellano, E. G., and Ottado, J. 2009. A filamentous hemagglutinin-like protein of Xanthomonas axonopodis pv. citri, the phytopathogen responsible for citrus canker, is involved in bacterial virulence. PLoS One 4:e4358.

Guo, W., Gao, J., Chen, Q., Ma, B., Fang, Y., Liu, X., Chen, G., and Liu, J.-Z. 2019. Crp-Like protein plays both positive and negative roles in regulating the pathogenicity of bacterial pustule pathogen Xanthomonas axonopodis pv. glycines. Phytopathology 109: 1171-1183.

Guo, Y., Figueiredo, F., Jones, J., and Wang, N. 2011. HrpG and HrpX play global roles in coordinating different virulence traits of Xanthomonas axonopodis pv. citri. Mol. Plant-Microbe Interact 24:649-661.

Harshey, R. M. 2003. Bacterial motility on a surface: Many ways to a common goal. Annu. Rev. Microbiol. 57:249-273.

Holmqvist, E., Wright, P. R., Li, L., Bischler, T., Barquist, L., Reinhardt, R., Backofen, R., and Vogel, J. 2016. Global RNA recognition patterns of post-transcriptional regulators $\mathrm{Hfq}$ and CsrA revealed by UV crosslinking in vivo. EMBO J. 35:991-1011.

Hu, Y., Zhang, J., Jia, H., Sosso, D., Li, T., Frommer, W. B., Yang, B., White, F. F., Wang, N., and Jones, J. B. 2014. Lateral organ boundaries 1 is a disease susceptibility gene for citrus bacterial canker disease. Proc. Natl. Acad. Sci. U.S.A. 111:E521-E529.

Huerta-Cepas, J., Forslund, K., Coelho, L. P., Szklarczyk, D., Jensen, L. J., von Mering, C., and Bork, P. 2017. Fast genome-wide functional annotation through orthology assignment by eggNOG-mapper. Mol. Biol. Evol. 34:2115-2122.

Huguet, E., Hahn, K., Wengelnik, K., and Bonas, U. 1998. hpaA mutants of Xanthomonas campestris pv. vesicatoria are affected in pathogenicity but retain the ability to induce host-specific hypersensitive reaction. Mol. Microbiol. 29:1379-1390.

Hyytiäinen, H., Montesano, M., and Palva, E. T. 2001. Global regulators ExpA (GacA) and KdgR modulate extracellular enzyme gene expression through the RsmA-rsmB system in Erwinia carotovora subsp. carotovora. Mol. Plant-Microbe Interact 14:931-938.

Jia, H., and Wang, N. 2020. Generation of homozygous canker-resistant citrus in the T0 generation using CRISPR-SpCas9p. Plant Biotechnol. J. 18:1990-1992.

Jia, H., Zhang, Y., Orbović, V., Xu, J., White, F. F., Jones, J. B., and Wang, N. 2017. Genome editing of the disease susceptibility gene CsLOB1 in citrus confers resistance to citrus canker. Plant Biotechnol. J. 15:817-823.

Katsowich, N., Elbaz, N., Pal, R. R., Mills, E., Kobi, S., Kahan, T., and Rosenshine, I. 2017. Host cell attachment elicits posttranscriptional regulation in infecting enteropathogenic bacteria. Science 355:735-739.

Kay, E., Humair, B., Dénervaud, V., Riedel, K., Spahr, S., Eberl, L., Valverde, C., and Haas, D. 2006. Two GacA-dependent small RNAs modulate the quorum-sensing response in Pseudomonas aeruginosa. J. Bacteriol. 188:6026-6033.

Klee, S. M., Mostafa, I., Chen, S., Dufresne, C., Lehman, B. L., Sinn, J. P., Peter, K. A., and McNellis, T. W. 2018. An Erwinia amylovora yjeK mutant exhibits reduced virulence, increased chemical sensitivity and numerous environmentally dependent proteomic alterations. Mol. Plant Pathol. 19:1667-1678.

Kusmierek, M., and Dersch, P. 2018. Regulation of host-pathogen interactions via the post-transcriptional Csr/Rsm system. Curr. Opin. Microbiol. 41:58-67.

Lee, J. H., Ancona, V., and Zhao, Y. 2018. Lon protease modulates virulence traits in Erwinia amylovora by direct monitoring of major regulators and indirectly through the Rcs and Gac-Csr regulatory systems. Mol. Plant Pathol. 19:827-840.

Leng, Y., Vakulskas, C. A., Zere, T. R., Pickering, B. S., Watnick, P. I., Babitzke, P., and Romeo, T. 2016. Regulation of CsrB/C sRNA decay by $\operatorname{EIIA}(\mathrm{Glc})$ of the phosphoenolpyruvate: Carbohydrate phosphotransferase system. Mol. Microbiol. 99:627-639.

Li, J., and Wang, N. 2011. The wxacO gene of Xanthomonas citri ssp. citri encodes a protein with a role in lipopolysaccharide biosynthesis, biofilm formation, stress tolerance and virulence. Mol. Plant Pathol. 12:381-396.

Li, J., and Wang, N. 2012. The gpsX gene encoding a glycosyltransferase is important for polysaccharide production and required for full virulence in Xanthomonas citri subsp. citri. BMC Microbiol. 12:31.

Li, J., and Wang, N. 2014. Foliar application of biofilm formationinhibiting compounds enhances control of citrus canker caused by Xanthomonas citri subsp. citri. Phytopathology 104:134-142.

Li, L., Li, J., Zhang, Y., and Wang, N. 2019. Diffusible signal factor (DSF)-mediated quorum sensing modulates expression of diverse traits in Xanthomonas citri and responses of citrus plants to promote disease. BMC Genomics 20:55.
Lu, X. H., An, S. Q., Tang, D. J., McCarthy, Y., Tang, J. L., Dow, J. M., and Ryan, R. P. 2012. RsmA regulates biofilm formation in Xanthomonas campestris through a regulatory network involving cyclic di-GMP and the Clp transcription factor. PLoS One 7:e52646.

Lu, Y., Rashidul, I. M., Hirata, H., and Tsuyumu, S. 2011. KdgR, an ICIR family transcriptional regulator, inhibits virulence mainly by repression of hrp genes in Xanthomonas oryzae pv. oryzae. J. Bacteriol. 193:6674-6682.

Marees, A. T., de Kluiver, H., Stringer, S., Vorspan, F., Curis, E., MarieClaire, C., and Derks, E. M. 2018. A tutorial on conducting genomewide association studies: Quality control and statistical analysis. Int. J. Methods Psychiatr. Res. 27:e1608.

Mukherjee, S., Yakhnin, H., Kysela, D., Sokoloski, J., Babitzke, P., and Kearns, D. B. 2011. CsrA-FliW interaction governs flagellin homeostasis and a checkpoint on flagellar morphogenesis in Bacillus subtilis. Mol. Microbiol. 82:447-461

Pagès, V., Koffel-Schwartz, N., and Fuchs, R. P. P. 2003. recX, a new SOS gene that is co-transcribed with the recA gene in Escherichia coli. DNA Repair (Amst.) 2:273-284.

Pannuri, A., Yakhnin, H., Vakulskas, C. A., Edwards, A. N., Babitzke, P., and Romeo, T. 2012. Translational repression of NhaR, a nove pathway for multi-tier regulation of biofilm circuitry by CsrA. J. Bacteriol. 194:79-89.

Potts, A. H., Vakulskas, C. A., Pannuri, A., Yakhnin, H., Babitzke, P., and Romeo, T. 2017. Global role of the bacterial post-transcriptional regulator CsrA revealed by integrated transcriptomics. Nat. Commun. 8:1596.

Pourciau, C., Lai, Y. J., Gorelik, M., Babitzke, P., and Romeo, T. 2020. Diverse mechanisms and circuitry for global regulation by the RNAbinding protein CsrA. Front. Microbiol. 11:601352.

Qi, Y. H., Huang, L., Liu, G. F., Leng, M., and Lu, G. T. 2020. PilG and $\mathrm{PilH}$ antagonistically control flagellum-dependent and pili-dependent motility in the phytopathogen Xanthomonas campestris pv. campestris. BMC Microbiol. 20:37.

Rigano, L. A., Siciliano, F., Enrique, R., Sendín, L., Filippone, P., Torres, P. S., Qüesta, J., Dow, J. M., Castagnaro, A. P., Vojnov, A. A., and Marano, M. R. 2007. Biofilm formation, epiphytic fitness, and canker development in Xanthomonas axonopodis pv. citri. Mol. PlantMicrobe Interact 20:1222-1230.

Romeo, T., and Babitzke, P. 2018. Global regulation by CsrA and its RNA antagonists. Microbiol. Spectr. 6:341-354.

Romeo, T., Vakulskas, C. A., and Babitzke, P. 2013. Post-transcriptional regulation on a global scale: Form and function of Csr/Rsm systems Environ. Microbiol. 15:313-324.

Sahr, T., Rusniok, C., Impens, F., Oliva, G., Sismeiro, O., Coppée, J.-Y. Y., and Buchrieser, C. 2017. The Legionella pneumophila genome evolved to accommodate multiple regulatory mechanisms controlled by the CsrA-system. PLOS Genet. 13:e1006629.

Schulmeyer, K. H., and Yahr, T. L. 2017. Post-transcriptional regulation of type III secretion in plant and animal pathogens. Curr. Opin. Microbiol. 36:30-36.

Schulte, F., Leßmeier, L., Voss, J., Ortseifen, V., Vorhölter, F. J., and Niehaus, K. 2019. Regulatory associations between the metabolism of sulfur-containing amino acids and xanthan biosynthesis in Xanthomonas campestris pv. campestris B100. FEMS Microbiol. Lett. 366:1-11.

Shannon, P., Markiel, A., Ozier, O., Baliga, N. S., Wang, J. T., Ramage, D., Amin, N., Schwikowski, B., and Ideker, T. 2003. Cytoscape: A software environment for integrated models of biomolecular interaction networks. Genome Res. 13:2498-2504.

Simon, R., Priefer, U., and Pühler, A. 1983. A broad host range mobilization system for in vivo genetic engineering: Transposon mutagenesis in gram negative bacteria. Nat. Biotechnol. 1:784-791.

Souza, D. P., Oka, G. U., Alvarez-Martinez, C. E., Bisson-Filho, A. W., Dunger, G., Hobeika, L., Cavalcante, N. S., Alegria, M. C., Barbosa, L. R. S. S., Salinas, R. K., Guzzo, C. R., and Farah, C. S. 2015. Bacterial killing via a type IV secretion system. Nat. Commun. 6:6453.

Sowa, S. W., Gelderman, G., Leistra, A. N., Buvanendiran, A., Lipp, S., Pitaktong, A., Vakulskas, C. A., Romeo, T., Baldea, M., and Contreras, L. M. 2017. Integrative FourD omics approach profiles the target network of the carbon storage regulatory system. Nucleic Acids Res. 45:1673-1686.

Su, H.-Z. Z., Wu, L., Qi, Y.-H. H., Liu, G.-F. F., Lu, G.-T. T., and Tang, J.-L. L. 2016. Characterization of the GntR family regulator HpaR1 of the crucifer black rot pathogen Xanthomonas campestris pathovar campestris. Sci. Rep. 6:19862.

Suzuki, K., Babitzke, P., Kushner, S. R., and Romeo, T. 2006. Identification of a novel regulatory protein $(\mathrm{CsrD})$ that targets the global regulatory RNAs CsrB and CsrC for degradation by RNase E. Genes Dev. 20:2605-2617. 
Szklarczyk, D., Gable, A. L., Lyon, D., Junge, A., Wyder, S., HuertaCepas, J., Simonovic, M., Doncheva, N. T., Morris, J. H., Bork, P., Jensen, L. J., and Mering, C. V. 2019. STRING v11: Protein-protein association networks with increased coverage, supporting functional discovery in genome-wide experimental datasets. Nucleic Acids Res. 47 (D1):D607-D613.

Tang, D. J., Chen, X. L., Jia, Y., Liang, Y. W., He, Y. P., Lu, T. T., Zhu, C. R., Han, B., An, S. Q., and Tang, J. L. 2020. Genome-wide screen and functional analysis in Xanthomonas reveal a large number of mRNA-derived sRNAs, including the novel RsmA-sequester RsmU. Mol. Plant Pathol. 21:1573-1590.

Tang, J., Lin, Y., Liao, Y.-Y., Huang, R.-X., Li, A.-Z., An, S.-Q., and Tang, D.-J. 2021. Extracellular amylase is required for full virulence and regulated by the global post-transcriptional regulator RsmA in Xanthomonas campestris pathovar campestris. Phytopathology 111:1104-1113.

Teper, D., Zhang, Y., and Wang, N. 2019. TfmR, a novel TetR-family transcriptional regulator, modulates the virulence of Xanthomonas citri in response to fatty acids. Mol. Plant Pathol. 20:701-715.

Tyanova, S., Temu, T., and Cox, J. 2016. The MaxQuant computational platform for mass spectrometry-based shotgun proteomics. Nat. Protoc. 11:2301-2319.

Vakulskas, C. A., Leng, Y., Abe, H., Amaki, T., Okayama, A., Babitzke, P., Suzuki, K., and Romeo, T. 2016. Antagonistic control of the turnover pathway for the global regulatory sRNA CsrB by the CsrA and CsrD proteins. Nucleic Acids Res. 44:7896-7910.

Vakulskas, C. A., Potts, A. H., Babitzke, P., Ahmer, B. M. M., and Romeo, T. 2015. Regulation of bacterial virulence by Csr (Rsm) systems. Microbiol. Mol. Biol. Rev. 79:193-224.

Vojnov, A. A., Slater, H., Daniels, M. J., and Dow, J. M. 2001. Expression of the gum operon directing xanthan biosynthesis in Xanthomonas campestris and its regulation in planta. Mol. Plant-Microbe Interact 14:768-774.

Walls, D., and Loughran, S. T. 2011. Tagging recombinant proteins to enhance solubility and aid purification. Methods Mol. Biol. 681:151-175.

Wang, B., Wu, G., Li, K., Ling, J., Zhao, Y., and Liu, F. 2021. A glycoside hydrolase family 99-like domain-containing protein modifies outer membrane proteins to maintain Xanthomonas pathogenicity and viability in stressful environments. Phytopathology 111:929-939.

Wang, N., Lu, S. E., Records, A. R., and Gross, D. C. 2006a. Characterization of the transcriptional activators SalA and SyrF, Which are required for syringomycin and syringopeptin production by Pseudomonas syringae pv. syringae. J. Bacteriol. 188:3290-3298.

Wang, N., Lu, S. E., Yang, Q., Sze, S. H., and Gross, D. C. 2006b. Identification of the syr-syp box in the promoter regions of genes dedicated to syringomycin and syringopeptin production by Pseudomonas syringae pv. syringae B301D. J. Bacteriol. 188:160-168.

Wei, B. L., Brun-Zinkernagel, A.-M., Simecka, J. W., Prüss, B. M., Babitzke, P., and Romeo, T. 2001. Positive regulation of motility and flhDC expression by the RNA-binding protein CsrA of Escherichia coli. Mol. Microbiol. 40:245-256.

Weilbacher, T., Suzuki, K., Dubey, A. K., Wang, X., Gudapaty, S., Morozov, I., Baker, C. S., Georgellis, D., Babitzke, P., and Romeo, T. 2003. A novel sRNA component of the carbon storage regulatory system of Escherichia coli. Mol. Microbiol. 48:657-670.

Wengelnik, K., and Bonas, U. 1996. HrpXv, an AraC-type regulator, activates expression of five of the six loci in the hrp cluster of Xanthomonas campestris pv. vesicatoria. J. Bacteriol. 178:3462-3469.

Yakhnin, A. V., Baker, C. S., Vakulskas, C. A., Yakhnin, H., Berezin, I., Romeo, T., and Babitzke, P. 2013. CsrA activates flhDC expression by protecting flhDC mRNA from RNase E-mediated cleavage. Mol Microbiol. 87:851-866.
Yakhnin, H., Pandit, P., Petty, T. J., Baker, C. S., Romeo, T., and Babitzke, P. 2007. CsrA of Bacillus subtilis regulates translation initiation of the gene encoding the flagellin protein (hag) by blocking ribosome binding. Mol. Microbiol. 64:1605-1620.

Yakhnin, H., Yakhnin, A. V., Baker, C. S., Sineva, E., Berezin, I., Romeo, T., and Babitzke, P. 2011. Complex regulation of the global regulatory gene csrA: CsrA-mediated translational repression, transcription from five promoters by $E \sigma^{70}$ and $E \sigma^{\mathrm{S}}$, and indirect transcriptional activation by CsrA. Mol. Microbiol. 81:689-704.

Yan, Q., Hu, X., and Wang, N. 2012. The novel virulence-related gene $n l x A$ in the lipopolysaccharide cluster of Xanthomonas citri ssp. citri is involved in the production of lipopolysaccharide and extracellular polysaccharide, motility, biofilm formation and stress resistance. Mol. Plant Pathol. 13:923-934.

Yan, Q., and Wang, N. 2011. The ColR/ColS two-component system plays multiple roles in the pathogenicity of the citrus canker pathogen Xanthomonas citri subsp. citri. J. Bacteriol. 193:1590-1599.

Yan, Q., and Wang, N. 2012. High-throughput screening and analysis of genes of Xanthomonas citri subsp. citri involved in citrus canker symptom development. Mol. Plant-Microbe Interact 25:69-84.

Yan, Y., Tang, J., Yuan, Q., Liu, L., Liu, H., Huang, J., Hsiang, T., and Zheng, L. 2021. iTRAQ-based quantitative proteomics reveals ChAcb1 as a novel virulence factor in Colletotrichum higginsianum. Phytopathology PHYTO-01-21-0028-R.

Yang, T. C., Leu, Y. W., Chang-Chien, H. C., and Hu, R. M. 2009. Flagellar biogenesis of Xanthomonas campestris requires the alternative sigma factors RpoN2 and FliA and is temporally regulated by FlhA, FlhB, and FlgM. J. Bacteriol. 191:2266-2275.

Yang, W. F., Chen, L., Liu, H. X., Hu, B. S., and Liu, F. Q. 2007. [Cloning, sequencing and fuctional study of gacA gene from Xanthomonas oryzae pv. oryzicola.]. Wei Sheng Wu Xue Bao 47:208-212.

Yu, G., Wang, L.-G., Han, Y., and He, Q.-Y. 2012. clusterProfiler: An R package for comparing biological themes among gene clusters. OMICS 16:284-287.

Zhang, J., Huguet-Tapia, J. C., Hu, Y., Jones, J., Wang, N., Liu, S., and White, F. F. 2017. Homologues of CsLOB1 in citrus function as disease susceptibility genes in citrus canker. Mol. Plant Pathol. 18:798-810.

Zhang, Y., Teper, D., Xu, J., and Wang, N. 2019a. Stringent response regulators (p)ppGpp and DksA positively regulate virulence and host adaptation of Xanthomonas citri. Mol. Plant Pathol. 20:15501565 .

Zhang, Y., Wu, G., Palmer, I., Wang, B., Qian, G., Fu, Z. Q., and Liu, F. 2019b. The role of a host-induced arginase of Xanthomonas oryzae pv. oryzae in promoting virulence on rice. Phytopathology 109:1869-1877.

Zhou, X., Hu, X., Li, J., and Wang, N. 2015. A novel periplasmic protein, VrpA, contributes to efficient protein secretion by the type III secretion system in Xanthomonas spp. Mol. Plant-Microbe Interact 28: 143-153.

Zhou, X., Teper, D., Andrade, M. O., Zhang, T., Chen, S., Song, W. Y., and Wang, N. 2018. A phosphorylation switch on lon protease regulates bacterial type III secretion system in host. MBio 9:1-17.

Zhou, X., Yan, Q., and Wang, N. 2017. Deciphering the regulon of a GntR family regulator via transcriptome and ChIP-exo analyses and its contribution to virulence in Xanthomonas citri. Mol. Plant Pathol. 18: 249-262.

Zhu, P. L., Zhao, S., Tang, J. L., and Feng, J. X. 2011. The rsmA-like gene $\operatorname{rsm} A(\mathrm{Xoo})$ of Xanthomonas oryzae pv. oryzae regulates bacterial virulence and production of diffusible signal factor. Mol. Plant Pathol. $12: 227-237$.

Zuker, M. 2003. Mfold web server for nucleic acid folding and hybridization prediction. Nucleic Acids Res. 31:3406-3415. 